\title{
Potential hazards of metal-contaminated soils in an estuarine impoundment
}

\author{
Glegg, Gillian
}

http://hdl.handle.net/10026.1/17054

10.1007/s11368-020-02821-x

Journal of Soils and Sediments: protection, risk assessment and remediation

Springer Verlag

All content in PEARL is protected by copyright law. Author manuscripts are made available in accordance with publisher policies. Please cite only the published version using the details provided on the item record or document. In the absence of an open licence (e.g. Creative Commons), permissions for further reuse of content should be sought from the publisher or author. 
Potential hazards of metal-contaminated soils in an estuarine impoundment Gillian A. Glegg, Cally Barratt, Alex Taylor, Emily Gulson \& Geoffrey E. Millward Journal of Soils and Sediments volume 21, pages 530-544(2021)

\section{Potential hazards of metal-contaminated soils in an estuarine impoundment}

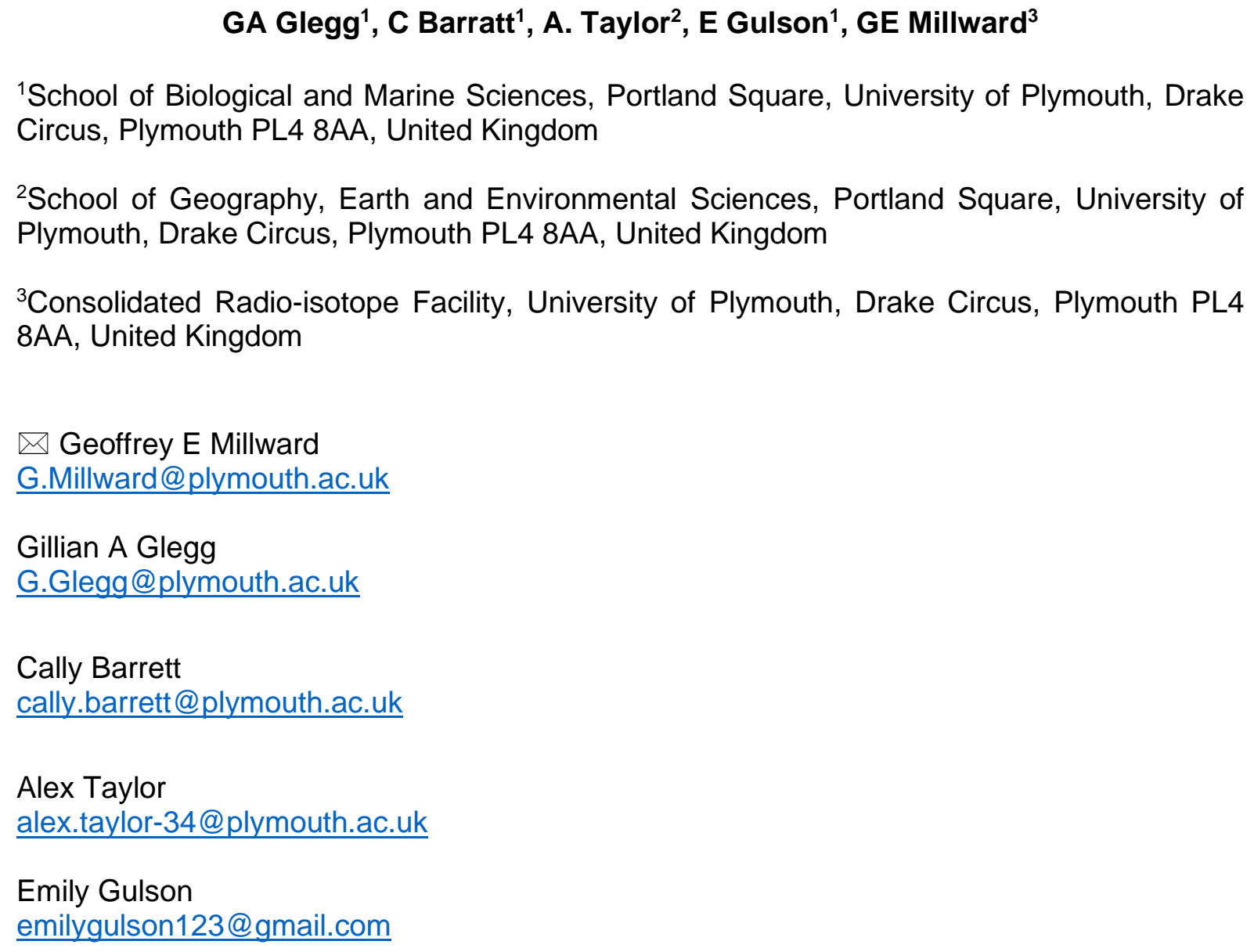

${ }^{1}$ School of Biological and Marine Sciences, Portland Square, University of Plymouth, Drake Circus, Plymouth PL4 8AA, United Kingdom

${ }^{2}$ School of Geography, Earth and Environmental Sciences, Portland Square, University of Plymouth, Drake Circus, Plymouth PL4 8AA, United Kingdom

${ }^{3}$ Consolidated Radio-isotope Facility, University of Plymouth, Drake Circus, Plymouth PL4 8AA, United Kingdom 


\section{Abstract}

44 Purpose A recreational impoundment was constructed in the mid-19 $9^{\text {th }}$ century on the mudflats reclaimed from the Plym Estuary (SW England) following salt marsh removal and infilling with waste soils from local catchments. Restoration of the salt marsh was attempted about 25 years ago when a regulated tidal exchange system was installed in the embankment separating the impoundment from the estuary. Currently, the embankment is disintegrating with the potential loss of the impounded soils, of unknown composition, to the estuary.

Methods Cores were obtained from the impoundment and the adjoining estuary, sectioned, dried and analysed. The geochronology of the soils, and estuarine sediments, was established using gamma ray spectroscopy to determine the activities of fallout radionuclides, ${ }^{137} \mathrm{Cs}$ and ${ }^{210} \mathrm{~Pb}$. The concentrations of $\mathrm{As}, \mathrm{Co}, \mathrm{Cr} \mathrm{Cu}, \mathrm{Fe}, \mathrm{Mn}, \mathrm{Ni}, \mathrm{Pb}, \mathrm{Rb}, \mathrm{Sn}$, $\mathrm{W}$ and $\mathrm{Zn}$ in the core sections were determined by quantitative $\mathrm{X}$-Ray Fluorescence spectrometry.

Results Below a shallow surface layer ( $>5 \mathrm{~cm}$ and post-1963) metal concentrations were high with several exceeding soil quality indices and enrichment factors (EFs) were elevated, in the sequence $\mathrm{Sn}>\mathrm{W} \approx \mathrm{As}>\mathrm{Cu}>\mathrm{Pb}$. Estimates of the total masses of particulate $\mathrm{Sn}, \mathrm{Pb}, \mathrm{As}$ and $\mathrm{Cu}$ available for down-estuary migration were significant.

Conclusions Given the ecotoxicological implications resulting from a loss of metalcontaminated soils into the estuary, a strategy for the future management of the impoundment is required. The conditions at this site are compared with ageing estuarine impoundments at other locations, where polluted sediments, or soils, could be vulnerable to release.

Keywords: estuary; impoundment; managed realignment; contaminated soils; release 


\section{Introduction}

Estuarine salt marshes and coastal wetlands have been impounded for more than two hundred years, mainly driven by a human need to increase the land available for alternative uses, such as agriculture, urban development and recreation (Gedan et al. 2009). Salt marshes are dependent on regular tidal intrusions to retain their geomorphology and fertility. Thus, impoundments may seriously impact the biogeochemical functioning of salt marshes, and their ecosystem value, particularly via interruption of natural supplies of sediments and plant propagules (Adam 2002). However, the growing imperatives introduced by climate change are causing an international re-assessment of the future for sea defences associated with the enclosure of salt marshes (Temmerman et al. 2013). Managed realignment involves the breaching, or complete removal, of impoundment barriers and, if required, the re-building of a new barrier landward (French 2006; Esteves 2011). This process promotes the incursion of estuarine water towards the foreshore, which may support the adventitious restoration of inter-tidal mud flats and salt marshes (Mazik et al. 2010; Mossman et al. 2012a; b). Also, it has been argued that barrier realignment forms a crucial part of an ecologically-based approach to utilising sea level rise positively leading to the reestablishment of salt marsh habitats that have a natural function in protecting coastlines (Temmerman et al. 2013). While managed realignment may have certain advantages, the potential recovery of the sediments, or soils, from impoundment can be uncertain. This is especially so where agriculture has taken place, inducing chemical and structural changes in the soil, leading to fluctuations in ecosystem biodiversity (Fernández et al. 2010; Spencer and Harvey 2012).

Regulated Tidal Exchange (RTE) is a modified form of managed realignment. Rather than completely removing the sea defences, a breach is made in an embankment, or a sea wall, coupled with the installation of a tide-gate, or strategically-placed culverts or weirs, to control the incursion of estuarine water into the impounded area (RSPB 2003; Esteves 2011). Consequently, tidal exchange between an impoundment and the estuary gives rise to 
overlying waters whose physico-chemical composition varies with river flow and tidal elevation and the influx of estuarine suspended solids and plant debris may create, over several years, a viable, salt marsh habitat (e.g. Mossman et al. 2012b). RTE systems have been employed across the world (ABPmer 2017) from the USA (Anisfeld et al. 1999; Boyd and Sommerfield 2017) to China (Liang and Wong 2003; Gu et al. 2018). In the UK, RTEs have been created to sustain aquatic wildlife activity (Dixon et al. 2008; RSPB 2003; MMO 2019) and to revive salt marshes (Masselink et al. 2017). Managed realignment is common in Europe (Wolters et al. 2005), where embanked polders have been restored to tidal inundation (i.e. depolderisation) using a Controlled Reduced Tide (CRT) method (Beauchard et al. 2011), a modified form of RTE. , For example, the Polder de Sébastopol (Vendée, France) was reclaimed from the Atlantic coast in 1856 to support agriculture. In 1978 its embankments collapsed and were re-built in the CRT manner to foster the creation of an active salt marsh system (Esteves 2011).

However, the contamination status of impoundment soils or sediments, in terms of their metal content, has been assessed in a limited number of cases, even so some have elevated concentrations (Table 1). The Hayle Estuary impoundment (Cornwall, UK)

\section{Table 1}

was constructed in 1834 , and fiited with a tide gate, has sediments highly impacted by inputs from metal mining (Rollinson et al. 2007; Aquatronics 2011). In the Scheldt Estuary (Lippenbroek, Belgium) a CRT was created by breaching the embankment of a polder to allow the incursion of estuarine water onto the metal-contaminated polder soils (Teuchies et al. 2012; 2013; Oosterlee et al. 2020). Furthermore, the potential release of metalcontaminated soils from ageing impoundments to the aquatic environment is exemplified by the scheme on the Blackwater Estuary (Essex, UK), where the failing barrier was manually breached in 1995 (Macleod et al. 1999; Emmerson et al. 2000; 2001).

Embankment failure illustrates the uncertainty associated with the long-term structural integrity of ageing sea defences enclosing estuarine and coastal impoundments. The 
stability of all marine structures, and their associated coastal ecosystems, are currently under enhanced environmental pressure from various factors associated with climate change, such as sea level rise, the frequency of storm surges, increased wave activity and highly variable river flows (Robins et al. 2016; Hanley et al. 2020). The durability of sea defences is particularly important in cases where the impounded soils, or sediments, are contaminated, which if released could impose near-term health risks to the surrounding waters. In some respects, this proposed scenario is somewhat similar to the release, and near-field dispersal, of contaminants from vulnerable, and poorly managed, coastal waste repositories (e.g. Hübner et al. 2010; Pope et al. 2011; Njue et al. 2012; O'Shea et al. 2018). Here we examine the soils of an impoundment with a failing embankment, which was constructed about 170 years ago when environmental control on the use of contaminated materials was not at today's standards (e.g.in the UK, the Control of Pollution Act, 1974). Consequently, knowledge about the composition of soils in this ageing impoundment requires urgent attention to ensure better long-term management should the embankment finally breakdown. The aim of this study was to examine the elemental content of the soils in an RTE impoundment located on the banks of an estuary and to assess the consequences of their release to the estuary. The objectives of the study were: (1) to determine the concentrations and spatial distributions of metal contaminants (As, Co, $\mathrm{Cr} \mathrm{Cu}, \mathrm{Fe}, \mathrm{Mn}, \mathrm{Ni}$, $\mathrm{Pb}, \mathrm{Rb}, \mathrm{Sn}, \mathrm{W}$ and $\mathrm{Zn}$ ), and their enrichment, in the soils of an estuarine impoundment; (2) to evaluate the contaminant loadings and potential impact due to the release of particulate metals to the estuary; (3) to consider potential management options for the containment, or controlled release, of contaminated sediments at this site and elsewhere. (10) 


\section{Methods}

\subsection{Study area}

The Blaxton Meadow impoundment is located on the upper Plym Estuary (Devon, England). The river rises $450 \mathrm{~m}$ above sea-level, its length is $32 \mathrm{~km}$, the catchment area covers 79.2 $\mathrm{km}^{2}$ and the River Plym is classed as having a good chemical status. The mean Plym river flow is $2.51 \mathrm{~m}^{3} \mathrm{~s}^{-1}$ with a $50 \%$ exceedance of $1.355 \mathrm{~m}^{3} \mathrm{~s}^{-1}$ and exceptional flow rates, $>30 \mathrm{~m}^{3}$ $\mathrm{s}^{-1}$, were recorded in December 2000 and 2012 (Riverlevels.uk 2018). A significant tributary input arises from the Torry Brook, which has a mean flow of $0.77 \mathrm{~m}^{3} \mathrm{~s}^{-1}$. It passes via a functioning clay mine where, via industrial discharges, it may acquire elevated suspended solid concentrations that are likely deposited in the upper estuary. The mean springs and neaps tidal ranges at Plymouth are $4.73 \mathrm{~m}$ and $2.20 \mathrm{~m}$, respectively.

\section{FIGURE 1}

The impoundment was constructed in 1852 to create a recreational area (Fig 1) for local inhabitants. The original salt marsh was removed and waste industrial solids were imported to create a level surface, which was raised slightly above high water neaps by the addition of a thin layer of soil. The source, or sources, of the particulate infill is not known. However, some of the material may have been sourced from the local catchments which are known for the extensive mining for metals from the early $17^{\text {th }}$ century, including $\mathrm{As}, \mathrm{Cu}, \mathrm{Pb}, \mathrm{Sn}$ and, more recently, W and the extraction of china clay (Jenkin, 2005). The impounded area covers an area of 5.5 ha and is fronted by a brick embankment ( $450 \mathrm{~m}$ long and $\sim 1.5 \mathrm{~m}$ high) (Fig. 1) built to completely exclude tidal intrusions from the estuary.

In 1995 a sluice gate was installed in the embankment to allow the tidally-controlled incursion of estuarine water, fostering the formation of a wetland. However, the operation of the sluice was short-lived as it was vandalised repeatedly and it was only made fully operational in 2003 (Mossman et al. 2012a). Colonisation by species of salt-tolerant plants, mainly Salicornia europaea, occurred within two years of inundation of estuarine water 
(RSPB 2003) and satellite images illustrate the time-dependent changes in the surface composition (Supplementary Information 1), which have actively promoted the site as a habitat for birds (RSPB 2003). Recently, the site owners, the National Trust, became concerned about the integrity of the embankment which has become unstable, consequent on tidal erosion and wave action. A technical report commissioned by the National Trust (Ruston and Long 2015) considered the engineering options associated with the future of the impoundment.

\subsection{Sample collection and processing}

Soil cores were collected in October 2017 (Fig. 1) from the impoundment, and a sediment core from the Plym Estuary at low water, using a root corer with a barrel diameter of $8 \mathrm{~cm}$. After collection the cores were extruded from the core barrel, laid in plastic half pipes and wrapped in polyethylene film. Impoundment cores were obtained to a depth where further penetration was inhibited by a stony layer, typically between $30 \mathrm{~cm}$ and $40 \mathrm{~cm}$. All cores were stored immediately after collection in a cold room, at $4^{\circ} \mathrm{C}$.

Prior to quantitative analysis, initial screenings of elemental profiles were made on each moist core, using a portable X-Ray Fluorescence instrument (Thermo Scientific Niton XL3t GOLD+). Four sediment cores identified for complete analyses were numbered as Sites 1 to 4, together with the sediment core from the Plym Estuary. Analyses for As and Pb at middepth were carried out on auxiliary cores A1 to A4 (Fig. 1). All cores were sectioned at $1 \mathrm{~cm}$ intervals and stored in pre-weighed plastic petri dishes. The samples were weighed wet after which they were frozen, then freeze-dried for $48 \mathrm{~h}$ and finally the dry weight was obtained. Each dried core section was separated across a $2 \mathrm{~mm}$ plastic mesh sieve to remove coarse particles.

\subsection{Gamma spectrometry}

To determine the activity concentrations of fallout radionuclides in the sieved sediment sections they were packed into individual aluminium containers with sealable lids to inhibit 
the escape of the gaseous decay product ${ }^{222} \mathrm{Rn}$. Before measurement the samples were incubated for a minimum of 24 days to allow attainment of secular equilibrium within the ${ }^{238} \mathrm{U}$ decay scheme.

Activity concentrations $\left(\mathrm{Bq} \mathrm{kg}^{-1}\right)$ of radionuclides were determined by gamma spectroscopy using a High Purity Germanium (HPGe) coaxial planar detector (Type: GMX50-83-LB-C-SMN-S; Ortec, UK), which had a full width-half maximum (FWHM) for the $1330 \mathrm{keV}$ line of ${ }^{60} \mathrm{Co}$ of $1.76 \mathrm{keV}$ and a relative efficiency of $25 \%$. The gamma spectrometer was calibrated using a natural soil, with low background activity, spiked with a radioactive traceable standard solution (80717-669 supplied by Eckert \& Ziegler Analytics, Georgia, USA). The standard calibration relationships were derived using ORTEC GammaVision ${ }^{\odot}$ software. Samples were counted for a minimum of $80,000 \mathrm{~s}$ and their activities, in $\mathrm{Bq} \mathrm{kg}^{-1}$, returned with a 2-sigma counting error. Quality control runs were conducted regularly using an IAEA world-wide proficiency test material, that is moss soil (IAEA-CU-2009-03), packed and sealed in the same geometry as the samples (Supplementary Information 2; Table S.1). The gamma energies of the target radionuclides were $46.5 \mathrm{keV}$ for total ${ }^{210} \mathrm{~Pb}_{\mathrm{T}}, 295$ and 352 $\mathrm{keV}$ for ${ }^{214} \mathrm{~Pb}$ and $661.6 \mathrm{keV}{ }^{137} \mathrm{Cs}$. The unsupported component of ${ }^{210} \mathrm{~Pb}\left({ }^{210} \mathrm{~Pb}\right.$ ex $)$ was estimated by subtracting the ${ }^{226} \mathrm{Ra}$ activity, which at radioactive equilibrium was determined by the gamma emissions of ${ }^{214} \mathrm{~Pb}$ i.e. ${ }^{210} \mathrm{~Pb}$ ex $={ }^{210} \mathrm{~Pb}-{ }^{214} \mathrm{~Pb}$.

\subsection{Wavelength-dispersive X-Ray fluorescence spectrometry}

Freeze-dried, sieved sediments ( 10 g) were disaggregated prior to being milled for 3 minutes at 300 rpm in a Pulverisette 5 planetary ball mill (Fritsch, Germany) using agate milling bowls and balls. Milled material was mixed with a polypropylene wax binding agent (Ceridust 6050M, Clariant, Switzerland) at a ratio of 1:4 (binder:sample) prior to being pressed into $40 \mathrm{~mm}$ diameter Al-backed pellets at $150 \mathrm{kN}$ using a TP20 manual press (Herzog, Germany). 
The elemental contents of the samples were determined by wavelength dispersive X-Ray

Fluorescence (WD-XRF) Spectrometry (Axios Max, PANalytical, Netherlands). The instrument was operated at $4 \mathrm{~kW}$ using a Rh target X-ray tube. During sequential elemental analysis, tube settings ranged from $25 \mathrm{kV}, 160 \mathrm{~mA}$ for low atomic weight elements up to 60 $\mathrm{kV}, 66 \mathrm{~mA}$ for higher atomic weight elements. All analyses were carried out using the "Pro Trace" analysis application with results validated using a stream sediment certified reference material (NCS DC 73309). Measured values were generally within 10\% of the certified values for the elements of interest (Supplementary Information 2; Table S.2). Repeatability of the procedure was determined by preparing 3 samples in triplicate with a relative standard deviation between replicates of $<10 \%$. Instrumental drift was assessed following internal quality control procedures using a multi-element glass sample.

\subsection{Determination of acid-extractable elements}

The soil sections of the core from Site 4, and sediment sections from the Plym core, were digested in $1 \mathrm{M} \mathrm{HCl}(\mathrm{pH} 0)$ to determine the potential "bioavailable" metals (Pope et al. 2011; Turner 2019). Approximately $0.2 \mathrm{~g}$ of dried sediment of each sample was accurately weighed, using a calibrated balance, into individual $50 \mathrm{~mL}$ glass beakers. Exactly $10 \mathrm{~mL}$ of $1 \mathrm{M} \mathrm{HCl}$ was added to each beaker and the contents constantly agitated and allowed to digest for $2 \mathrm{~h}$ at room temperature. Afterwards $6 \mathrm{~mL}$ of the digest from each of the beakers was extracted using a calibrated pipette and transferred to $50 \mathrm{~mL}$ volumetric flasks, which were made up to the mark using Milli-Q water and the contents of the sealed flasks thoroughly mixed.

The digests were analysed by inductively coupled plasma-mass spectrometry (ICP-MS) (iCAP RQ; Thermo Fisher Scientific, UK). The instrument was calibrated using multi-element standards prepared at an appropriate concentration range in the same matrix as the digested samples. Wash cycles, using $10 \% \mathrm{HNO}_{3}$, were performed between analyses to minimise contamination. After each batch of 10 analyses, a check sample was used to 
261 blank, were in the range $6-12 \mu \mathrm{g} \mathrm{L}^{-1}$ for all the metals.

262

263

264

265

266

267

268

269

270

271

272

273

274

275

276

277

278

279

280 


\section{Results and discussion}

282

283

284

285

286

287

288

289

290

291

292

293

294

295

296

297

298

299

300

301

302

303

304

\subsection{Fallout radionuclides}

\subsubsection{Depth profiles}

The ${ }^{137} \mathrm{Cs}$ activities in the impoundment soils result from its atmospheric fallout from nuclear weapons testing, which began in the 1940s and reached a maximum in 1963 (Walling and He 2000). These events gave a well-defined peak in ${ }^{137} \mathrm{Cs}$ in each core (Fig 2: 1a to 4a), at approximately $5 \mathrm{~cm}$ depth, coincident with the 1963 testing maximum. Thus, the shallow top

\section{FIGURE 2}

layer of sediment was deposited post-1963. The ${ }^{137} \mathrm{Cs}$ inventories for Sites 1 to 4 are 1,473 , 1,530, 1,127 and 1,177 Bq m${ }^{-2}$, respectively, values which compare well with the 2018 northern hemisphere decay corrected fallout of ${ }^{137} \mathrm{Cs}$ in annual precipitation (960 mm for SW England) of $1,460 \mathrm{~Bq} \mathrm{~m}^{-2}$ (Walling and $\mathrm{He} 2000$ ). Our ${ }^{137} \mathrm{Cs}$ depth profiles are similar to those found in two Delaware Bay (USA) impoundments that were fitted with tide gates in the mid-1980s (Boyd and Sommerfield 2016). In the Delaware Bay case, the observed peaks in ${ }^{137} \mathrm{Cs}$ activities were also confined to the top $10 \mathrm{~cm}$ of the cores and the inventories were in the range $1,120-3,150 \mathrm{~Bq} \mathrm{~m}^{-2}$.

The sediment core from the Plym Estuary comprised particulate matter that was a light grey in colour, likely arising from the supply of waste particulate solids emanating from commercial clay mining in the Plym catchment (Jenkin 2005). Compared to the impoundment soils, the estuarine sediment core had relatively low activities of ${ }^{137} \mathrm{Cs}$ in the near-surface sediments (Fig 2: $\mathrm{Pa}$ ), typically $<5 \mathrm{Bg} \mathrm{kg}^{-1}$, and were below the minimum detectable activity after a depth of $13 \mathrm{~cm}$. Thus, the low ${ }^{137} \mathrm{Cs}$ activities suggest the estuarine clay-like sediments had been excavated from below ground and released to the environment after the significant period of ${ }^{137} \mathrm{Cs}$ fallout about 50 years ago. Consequently, the ${ }^{137} \mathrm{Cs}$ 
inventory for the Plym core was $180 \mathrm{~Bq} \mathrm{~m}^{-2}$, which was approximately an order of magnitude lower inventory than the cores from the impoundment.

The activities of total ${ }^{210} \mathrm{~Pb}$ were at a maximum near the soil surface with an approximate exponential decay down-core. The activities of total ${ }^{210} \mathrm{~Pb}$ were in equilibrium with ${ }^{214} \mathrm{~Pb}$ at a depth of approximately $10 \mathrm{~cm}$ for each impoundment core (Fig 2: $1 \mathrm{~b}$ to $4 \mathrm{~b}$ ). The activities of ${ }^{214} \mathrm{~Pb}$, representing the activities of ${ }^{226} \mathrm{Ra}$ at equilibrium, are almost uniform with depth in each core, with activities centred about $50 \mathrm{~Bq} \mathrm{~kg}^{-1}$. The estuarine core sections had total ${ }^{210} \mathrm{~Pb}$ and ${ }^{214} \mathrm{~Pb}$ activities with a similar range to those in the impoundment with a down-core exponential decay (Fig 2: $\mathrm{Pb}$ ), importantly ${ }^{214} \mathrm{~Pb}$ had a trend in common with the impoundment cores all having relatively constant and similar values. The inventories of all five cores were in the range 9,000 to $24,900 \mathrm{~Bq} \mathrm{~m}^{-2}$ which were significantly higher than the values $\left(3,680-6,800 \mathrm{~Bq} \mathrm{~m}^{-2}\right)$ obtained in cores from an impoundment in the USA (Boyd and Sommerfield, 2016), indicating potential differences in ${ }^{238} \mathrm{U}$ sources of ${ }^{222} \mathrm{Rn}$, the precursor of fallout ${ }^{210} \mathrm{~Pb}$.

\subsubsection{Age-Depth Relationships}

The ages of the soils, and sediments, in the core sections were assessed using the methodology described by Appleby (2001) and applied recently in our lab on lake sediments (Wynants et al. 2020). The constant rate of supply (CRS) model was used because of its inclusion of changes in the initial ${ }^{210} \mathrm{~Pb}_{\mathrm{ex}}$ activity and sedimentation rates. The age-depth relationship was estimated using 2018 as the starting date and the ages were calibrated against the maximum fallout of ${ }^{137} \mathrm{Cs}$ which occurred in 1963, 55 years previously. The agedepth relationships for the impoundment cores (Fig 2: 1c to 4c) had similar gradients indicating similar histories for the soils. However, the sedimentation rates were sitedependent in that Sites 1 and 2, close to the sluice gate (Fig 2: 1c; 2c), had similar increasing trends in sedimentation, in the range $0.10-0.80 \mathrm{~kg} \mathrm{~m}^{-2}$ year $^{-1}$. In contrast, the sedimentation at Sites 3 and 4 (Fig 2: 3c; 4c), both of which are set back from the tide gate, 
was significantly lower and relatively constant typically $0.4 \mathrm{~kg} \mathrm{~m}^{-2}$ year ${ }^{-1}$. The impoundment sedimentation rates were relatively low and were similar in value to those found in two impoundments in the Delaware Estuary (USA), where the mineral sedimentation accumulation rates were in the range $0.136-0.529 \mathrm{~kg} \mathrm{~m}^{-2}$ year $^{-1}$ (Boyd and Sommerfield 2016). However, the sedimentation rates in impoundments located on Long Island (USA) were higher and, based on the down-core distributions of ${ }^{137} \mathrm{Cs}$ fallout, were in the range 0.42 to $2.2 \mathrm{~kg} \mathrm{~m}^{-2}$ year-1 $^{-1}$ (Anisfeld et al. 1999). Elevated sedimentation rates, estimated over several years, were also observed in the Scheldt Estuary where for a full tidal exchange (FTE) intertidal habitat they were 25 times higher than in a nearby partial exchange CRT system (Oosterlee et al. 2020).

The core from the Plym Estuary, consisting of cohesive sediment, had an age-depth relationship that was much steeper than those from the impoundment, reflecting on-going deposition within the estuary (Fig. 2: Pc). The sedimentation in the top $12 \mathrm{~cm}$ of the core was variable, in a range of $0.10-0.80 \mathrm{~kg} \mathrm{~m}^{-2}$ year-1, with a peak about four decades ago ( 1980), followed by a trough and then an increase over two decades to the present day.

\subsection{Elemental concentrations}

\subsubsection{Mass dominant elements}

The impoundment cores had significant differences between the total $\mathrm{Fe}, \mathrm{Mn}$ and $\mathrm{Rb}$ concentrations compared to the core from the Plym Estuary (Fig 3). Thus, the total Fe concentrations in the soils of the impoundment were in a range of $22,900-46,500 \mathrm{mg} \mathrm{kg}^{-1}$ and the Fe concentrations below $5 \mathrm{~cm}$ were relatively constant throughout the depth, although there was some variability at depths $>30 \mathrm{~cm}$, especially at Sites 1 and 4 (Fig. 3a).

\section{FIGURE 3}

Manganese concentrations for impoundment cores were relatively uniform, covering a narrow range of 300-700 $\mathrm{mg} \mathrm{kg}^{-1}$, throughout the depth range 5-30 cm. However, small 
peaks in the Mn concentrations were obtained in the upper $\sim 5 \mathrm{~cm}$ and at $>30 \mathrm{~cm}$ (Fig. 3b). The $\mathrm{Rb}$ concentrations in the impoundment soils were in the range $250-400 \mathrm{mg} \mathrm{kg}^{-1}$ and were relatively constant throughout the depth (Fig. 3c). The relatively high $\mathrm{Rb}$ concentrations are consistent with the $\mathrm{Rb}$ content of illite clay minerals (Köster, 1996), which, together with the light grey colour of the sediment, indicated a potential clay mineral input from mining in the Plym catchment.

In contrast, the Plym Estuary core had an irregular depth dependence of total Fe, Mn and $\mathrm{Rb}$ concentrations that were affected by significant fluctuations in concentration between 9 and $17 \mathrm{~cm}$. The Plym Estuary core exhibited concentrations of Fe, in the range 15,500 to $38,200 \mathrm{mg} \mathrm{kg}^{-1}$ that were lower than those in the impoundment, except where a peak concentration occurred at $10.5 \mathrm{~cm}$ depth (Fig. 3a). Similarly, the concentrations of particulate Mn were relatively constant, except for a well-defined maximum concentration again at 10.5 cm depth (Fig. 3b). The Rb concentrations in the Plym were significantly higher than those in the impoundment and had a mean concentration of $430 \pm 45 \mathrm{mg} \mathrm{kg}^{-1}$, presumably because the clay-like sediment was finer and more cohesive than the soils from the impoundment.

The coherence in the depths and shapes of the maximum concentrations of $\mathrm{Fe}$ and $\mathrm{Mn}$ in the Plym core gave a strong positive statistical relationship between Fe and Mn throughout the core $\left(R^{2}=0.756 ; p<0.001 ; n=25\right)$. This suggests that these redox-sensitive elements are involved in a common chemical process that created a redox boundary at approximately 11 $\mathrm{cm}$, where dissolved species of Fe and Mn precipitate as ferromanganese oxides. The redox boundary is also associated with a notable decrease in particulate Rb concentrations between 11 and $15 \mathrm{~cm}$. In this case, the Plym core has a strong negative statistical relationship between $\mathrm{Fe}$ and $\mathrm{Rb}\left(\mathrm{R}^{2}=0.708 ; \mathrm{p}<0.001 ; n=25\right)$. The reason for the inverse relationship between $\mathrm{Fe}$ and $\mathrm{Rb}$ is not clear unless the particulate $\mathrm{Rb}$ is exchangeable and is released to the dissolved phase by the chemical conditions induced by the formation of ferromanganese oxides. 


\subsubsection{Contaminant elements}

384 The mean concentrations $( \pm 1$ SD) of the contaminant elements in the Plym core and impoundment cores are summarised in Table 2. The group of elements consisting of Co, Cr, $\mathrm{Ni}, \mathrm{Pb}$ and $\mathrm{Sn}$ have concentrations in the Plym core that are generally lower than those in

\section{TABLE 2}

388

389

390

391

392 the impoundment cores, whereas for $\mathrm{As}, \mathrm{Cu}, \mathrm{W}$ and $\mathrm{Zn}$ the concentrations of the Plym core overlap with the concentrations in the impoundment cores (Fig. 4). Cobalt (Fig. 4a) and $\mathrm{Cr}$

\section{FIGURE 4}

(Fig. 4b) had soil concentrations that showed little variation with depth at each of the sites. Cobalt concentrations in the soils were low, although they varied somewhat with depth and Co at Site 2 decreased towards the surface. The concentrations of $\mathrm{Cr}$ increased from the surface to about $10 \mathrm{~cm}$, after which all 4 sites were constant with depth. Nickel (Fig. 4c) also had relatively low concentrations in the impoundment soils with similar concentrations for cores from Sites 2 and 4 and slightly higher concentrations at Sites 1 and 3 . The concentrations of Ni were constant from the surface to about $30 \mathrm{~cm}$, after which they declined in each core. Lead concentrations (Fig. 4d) at Sites 2 and 4 were of similar magnitude and were uniform with depth, whereas Sites 1 and 3 had similar, elevated concentrations. Site 1 had a significant $\mathrm{Pb}$ peak at $30 \mathrm{~cm}$. The $\mathrm{Pb}$ concentrations in the Plym Estuary profile were uniform ranging from $55-95 \mathrm{mg} \mathrm{kg}^{-1}$. The additional cores A1 to A4 (Supplementary Information 3) had elevated $\mathrm{Pb}$ concentrations in the top $27 \mathrm{~cm}$ that were in the range $50-200 \mathrm{mg} \mathrm{kg}^{-1}$. Tin concentrations in all impoundment cores (Fig. 4e) showed substantial variability and the concentrations were elevated, especially at Sites 2 and 3, where the maximum concentration was $810 \mathrm{mg} \mathrm{kg}^{-1}$. There was little fluctuation in $\mathrm{Sn}$ concentrations the Plym Estuary core which were significantly lower than those from the impoundment. 

overlapped significantly with their concentrations in the Plym sediments. The depthdependences of As concentrations for Sites 1 and 2 were closely aligned (Fig. 4f) and at Site 4 As was higher in the upper layers and had a distinct As peak at $\sim 40 \mathrm{~cm}$ depth. Arsenic in the Plym sediments had minor variations in concentration with depth, which were confined to a narrow range of $50-90 \mathrm{mg} \mathrm{kg}^{-1}$. The As concentrations in the cores $\mathrm{A} 1$ to $\mathrm{A} 4$ (Supplementary Information 2) were mainly elevated and in the range 0-150 $\mathrm{mg} \mathrm{kg}^{-1}$. Concentrations of $\mathrm{Cu}$ at Sites 1, 2 and 4 (Fig. $4 \mathrm{~g}$ ) were similar up to $30 \mathrm{~cm}$, after which the Cu concentrations exhibited a decreasing trend with depth, whereas the Cu concentrations at Site 3 were elevated by comparison with the other sites. The Plym Estuary sediments up to $10 \mathrm{~cm}$ depth had higher Cu concentrations than Sites 1,2 and 4 after which the Plym concentrations decreased with depth. The W concentrations in the impoundment soils (Fig. 4h), and the Plym Estuary sediments, cover a similar in range. However, impoundment Sites 1 and 4 show significant peaks at depth. The depth-distributions of $Z n$ concentrations for Sites 2 and 4 (Fig. 4i) were relatively uniform. In contrast, Sites 1 and 3 also showed a similar trend but the concentrations for these cores were marginally higher. The Plym Estuary core had variable concentrations of total $\mathrm{Zn}$, together with a general trend of decreasing concentrations up to $16 \mathrm{~cm}$ depth, after which the concentrations increased.

\subsubsection{Evaluation of elemental distributions}

The concentrations of each element in the impoundment soils, and the Plym sediments, are compared with their median concentrations obtained from analyses of 5,670 top soil samples (15 cm depth, dried and mixed), collected from sites across England and Wales (Rawlins et al. 2012). The sample collection avoided large urban areas and areas where the concentrations of most elements may have been altered by processes such as the atmospheric deposition of industrial contaminants or the release of waste solids. In our data analyses the median soil concentration is preferred because it is a better measure of the 
mid-point concentration because it reduces any bias that may be introduced into the mean by the outliers, compared to the overall dataset.

The distributions of the elemental concentrations in the impoundment suggest the original infilling with waste soils appears to have been applied in an uneven manner, as shown by variability of downcore profiles, for example, $\mathrm{Pb}, \mathrm{Sn}, \mathrm{As}, \mathrm{Cu}$ (Fig. 4). The comparisons between the measured concentrations and the median elemental concentrations fall into three groups. Firstly, only Mn (Fig. 3b) had concentrations in the impoundment samples that were below the median values. Secondly, Co (Fig. 4a) and arguably Ni (Fig. 4c) had impoundment concentrations that cohered with their median soil values. The third group involves Fe (Fig. 3a), Rb (Fig. 3c), Pb, Sn, As, Cu, W and Zn (Fig. 4) all of which had impoundment soil concentrations above, significantly so in some cases, the median value for uncontaminated soils in England and Wales (Rawlins et al. 2012).

There are also questions as to the extent to which these elevated soil concentrations are above what are considered to be the "normal background concentrations (NBC)" in UK soils (Ander et al. 2013). The NBCs were determined from the analysis of $>30,000$ soil samples from across the UK, where for $\mathrm{As}, \mathrm{Cu}, \mathrm{Ni}$ and $\mathrm{Pb}$ the NBCs were estimated as 32, 62, 42 and $180 \mathrm{mg} \mathrm{kg}^{-1}$, respectively. Thus, the elemental concentrations in the impoundment cores (Fig. 4) indicate that the NBCs for As and Cu were exceeded in each core, whereas our measured concentrations of $\mathrm{Pb}$ at Site 3 were only ones elevated over the NBC value. The NBC for Ni was not surpassed in any of the cores. Thus, a comparison of our data with the NBC norms leads to the conclusion that $\mathrm{As}$ and $\mathrm{Cu}$, and potentially $\mathrm{Pb}$, are seriously contaminated in the impoundment soils.

The ranges of total metal concentrations in the soils of the Blackwater Estuary managed retreat site (UK) were lower than those recorded here (Table 1). The relatively low soil metal concentrations at the Blackwater site were similar to those in the sediments of RTE impoundments in Hong Kong (Liang and Wong 2003) and in the tidal flats of the Chongming Dongtan impoundment, China (Ma et al. 2015). However, a polder restored to tidal influence, in the Scheldt Estuary (Teuchies et al. 2013), had elevated metal concentrations in the soils 
and the concentrations of $\mathrm{Cr}, \mathrm{Pb}, \mathrm{Zn}$ exceeded those found in the Plym impoundment (Table

463 1). An ageing impoundment in the Hayle Estuary, UK, which received inputs from the mining industry had relatively low Sn concentrations, whereas $\mathrm{As}, \mathrm{Cr}, \mathrm{Pb}$ were similar in magnitude to those in the Plym impoundment. However, the $\mathrm{Cu}$ and $\mathrm{Zn}$ concentrations in the Hayle Estuary impoundment (Table 1) were significantly greater due to mining activity in the catchment. In the lower Plym Estuary sedimentary metals in two cores from an inlet, accommodating a boat yard, had concentrations of $\mathrm{Cu}, \mathrm{Pb}$ and $\mathrm{Zn}$ that were generally higher than those in our upper Plym core (Table 1), whereas Sn concentrations in the inlet cores were lower by at least an order of magnitude (Takahashi et al. 2012). Towards the mouth of the Plym Estuary sediments were found with elevated $\mathrm{Pb}$ concentrations, in the range 410$500 \mathrm{mg} \mathrm{kg}^{-1}$ (Turner 2019).

It is also important to question whether the elemental concentrations released from decaying coastal landfills (Hübner et al. 2010; Pope et al. 2011; O'Shea et al. 2018) were as elevated as those recorded here. Total metal concentrations in foreshore sediments close to these facilities are considerably lower than those in the Plym impoundment, with the possible exception of $\mathrm{Zn}$ (Table 1). Sediments adjacent to a landfill had $\mathrm{Cu}$ and $\mathrm{Pb}$ concentrations that were lower than those in the Plym impoundment, although the $\mathrm{Zn}$ concentrations were comparable (Njue et al. 2012). In conclusion, metals in the soils/sediments found adjacent to coastal landfills in the UK are relatively low compared to those in the Plym impoundment.

\subsubsection{Enrichment factors}

Estimations of elemental Enrichment Factors (EFs) require a normalising element which is free from contamination in order to account for grain size and mineralogical differences in the samples. Aluminium is usually adopted as the normalising element but it was not measurable with our WD-XRF methodology. Thus, Rb concentrations were determined as a geochemical proxy for the estimations of the EFs recently applied for marine solid phases from Plymouth waters (Turner 2019). The EFs were estimated according to Equation 1: 
$488 \quad \mathrm{EF}=\frac{\left\{\frac{\mathrm{M}}{\mathrm{Rb}}\right\}}{\left\{\frac{\mathrm{M}_{\mathrm{Ref}}}{\mathrm{Rb}_{\text {Ref }}}\right\}}$

489

490

491

492

493

494

495

496

497

498

499

500

501

502

503

504

505

506

507

508

509

510

where $\mathrm{M}$ and $\mathrm{Rb}$ are the measured total concentrations of metal $\mathrm{M}$ and $\mathrm{Rb}$ in the soils and $\mathrm{M}_{\text {Ref }}$ and $\mathrm{Rb}_{\mathrm{Ref}}$ are their total reference concentrations. To make a realistic assessment of the EFs, the total reference concentrations of the elements were taken as their median concentrations in the soils from England and Wales (Rawlins et al. 2012).

The general range of EFs vary from $E F<1$ indicating no enrichment, $1<\mathrm{EF}<3$ minor enrichment, $3<\mathrm{EF}<5$ moderately enriched, $5<\mathrm{EF}<10$ moderate to severe enrichment, $10<E F<25$ severe enrichment to $E F>25$ very severe enrichment. Thus, the EFs estimated for the impoundment soils, and the Plym Estuary sediments, showed that several elements had no enrichment, EF<1, including Fe (range 0.13 to 0.32 ), Mn (range 0.14 to 0.19 ) and $\mathrm{Co}, \mathrm{Cr}, \mathrm{Ni}$ and $\mathrm{Zn}$ all have $\mathrm{EF}<0.6$. In contrast, $\mathrm{Sn}$ had very severe enrichment in the

\section{FIGURE 5}

impoundment cores, whereas W was moderately enriched, As and Cu had minor to moderate enrichment and $\mathrm{Pb}$ was classed as not being enriched (Fig. 5). Thus, the EFs for metals in the impoundment soils were in the sequence $\mathrm{Sn}>\mathrm{W} \approx \mathrm{As}>\mathrm{Cu}>\mathrm{Pb}>\mathrm{Co} \sim \mathrm{Cr} \sim \mathrm{Ni} \sim \mathrm{Zn}$. The Plym sediment core had EFs lower than those in the impoundment, particularly for As, $\mathrm{Cu}$ and $\mathrm{Pb}$ where the $\mathrm{EF} \leq 1$.

\subsection{Implications of impoundment failure}

\subsubsection{Mobilisation of contaminated soils}

Removal of some, or all, of the embankment may result in regular tidal flooding of the soils causing their intermittent remobilisation, coupled with their down-estuary transport. The elevated EFs raise concerns about the consequences of the estuarine re-distribution of metal contaminated soils. Thus, the inventories of the metals, I $\left(\mathrm{g} \mathrm{m}^{-2}\right)$, in each core that 
511 were available for dispersal from the impoundment were estimated by integrating the metal

512 inventories of each core section, $\mathrm{i}$, over the number of sections in the core, $\mathrm{n}$ :

$513 \quad \mathrm{I}=\frac{1}{\mathrm{~A}} \sum_{\mathrm{i}=1}^{\mathrm{i}=\mathrm{n}} \mathrm{c}_{\mathrm{i}} \cdot \mathrm{m}_{\mathrm{i}}$

514 where $c_{i}$ is the metal concentration of the metal in section $\mathrm{i}, \mathrm{mg} \mathrm{kg}^{-1}, \mathrm{~m}_{\mathrm{i}}$ is the mass of dried

515 soil in section $\mathrm{i}, \mathrm{kg}$, and $\mathrm{A}$ is the area of the core barrel, $\mathrm{m}^{2}$. The approximate total masses

516 (tonnes) of each metal were obtained by multiplying the mean inventories over the total area

517 of the impoundment, $55,000 \mathrm{~m}^{2}$. The approximate total masses in the impoundment are in

518 the sequence $\mathrm{Sn}>\mathrm{Pb} \sim \mathrm{As} \sim \mathrm{Zn}$ (Table 3). A comparison of the inventories of metals in the

\section{TABLE 3}

520 Plym core with those in the impoundment shows that impoundment inventories are higher by

521 a factor of two, and three for Sn. Clearly, the eroded impoundment soils may migrate down estuary while mixing with the pre-existing suspended sediment mobilised during tidal incursion, in which case some dilution could occur. Since the Plym Estuary is not protected under designated marine habitats policy, management options for remediation of the contaminated sediments needs to be considered (Chen et al. 2017). To avoid down-estuary contamination the soils could be removed by dredging and then disposed of at a designated offshore site. The UK Action Levels on dredged material (Table 4) provide a basis for decision-making on sediment disposal at sea (DEFRA 2003). Our mean soil concentrations

for $\mathrm{As}, \mathrm{Cr}, \mathrm{Cu}$ and $\mathrm{Pb}$ are higher than criterion $\mathrm{A} 1$, whereas criterion $\mathrm{A} 2$ is only exceeded by the As concentrations at three sites and Cu concentrations at one site. Thus, the elevated values for $\mathrm{As}$, and $\mathrm{Cu}$, appear to preclude the possibility of sea disposal.

Given that off-shore disposal of the contaminated soils is highly unlikely, managed retreat may offer some advantages, especially if a new embankment installed further back.

535 Encouraging the breach and removing more of the embankment to allow estuarine intrusion 
would also contribute to better support the development of the salt marsh, with the protective

537 benefits that brings (Temmerman et al. 2013). The elevated concentrations of some metals

538 in the soils, implies their re-mobilisation presents an environmental risk, particularly to the sediment dwelling biota down-estuary. However, capping and heightening the surface of the impoundment using responsibly sourced sediments (e.g. clean dredged alluvial material) may also provide additional protection, conditional on the interplay between the tidal elevation and geomorphology (VanZomeren et al. 2018). Mobilisation of the contaminated subsurface layer mixed with the uncontaminated alluvial material by water turbulence may also produce particulate mixtures with overall lower elemental concentrations.

\subsubsection{Biological impact}

The potential biological impact of the total elemental concentrations in the soils may be assessed by comparison with the threshold effect levels (TEL) and probable effect levels (PEL) proposed by the Canadian Sediment Quality Guidelines (CCME 1995). The elements of particular interest are $\mathrm{As}$ and $\mathrm{Pb}$ because the mean concentrations in all cores surpass the value of the PEL (Table 4), whereas the PEL for $\mathrm{Cu}$ is only exceeded in Sites 3 and 4. The PEL values for $\mathrm{Cr}$ and $\mathrm{Zn}$ are not exceeded in any of the cores. The extent to which tidal inundation and wave action would mobilise contaminated sedimentary layers from the Plym impoundment is unknown at present. However, the particulate metal contaminants released from the impoundment, particularly $\mathrm{As}$, and $\mathrm{Pb}$, may migrate down-estuary, where they may be taken up by biota. In mid-estuary there are significant beds of Scrobicularia plana, Nereis diversicolor and Littorea littorea which, hitherto, contain relatively low metal concentrations in their tissues (Langston et al. 2003).

While the fore-going assessment is based on the total metal concentrations, the potential bioavailability of the elements was assessed using extractions by $1 \mathrm{M} \mathrm{HCl}$ of the core sections from Site 3 . Thus, $82 \pm 11 \%$ of $\mathrm{Pb}$ was released, $70 \pm 10 \%$ of $\mathrm{Cu}, 44 \pm 6 \%$ of $\mathrm{As}$ and $12 \pm 5 \%$ of $\mathrm{Zn}$ and less than $7 \%$ of $\mathrm{Cr}, \mathrm{W}$ and $\mathrm{Sn}$ (Fig. $6 \mathrm{a}$ ). Sn and $\mathrm{W}$ showed minimal 
remobilisation with means of $2.4 \%$ and $0.76 \%$, respectively. Not shown are the data for the remobilisation of $\mathrm{Mn}$ and $\mathrm{Fe}$, which had $0.3 \%$ and $13 \%$ remobilised, respectively. $\mathrm{Cr}$ and $\mathrm{Sn}$ are tightly bound to the soils and not readily released by the extract. The sequence in the percentage metal released by $1 \mathrm{M} \mathrm{HCl}$ from the Plym sediment core (Fig. 6b) was generally similar to the impoundment soils, where $36 \pm 3 \%$ of As and $62 \pm 4 \%$ of Cu were released. However, more Zn $(51.6 \pm 4.2 \%)$ and slightly higher $\operatorname{Cr}(10.5 \pm 1.5 \%)$ were mobilised. Our metal bioavailability estimates are compared to those in foreshore sediments contaminated by metal leakage from a coastal waste dump (Table 1), where Pope et al. (2011) found Cr, $\mathrm{Pb}$ and $\mathrm{Zn}$ had similar $1 \mathrm{M} \mathrm{HCl}$ bioavailability to the values found in this study, whereas As and $\mathrm{Cu}$ both had lower values.

Of interest is the fate of soil particles with elevated particulate concentrations of toxins, such as As, if they are repeatedly taken up by estuarine organisms. For example, the mean total As concentration for soils from Site 3 was $177 \mathrm{mg} \mathrm{kg}^{-1}$. Assuming the $1 \mathrm{M} \mathrm{HCl}$ extract is a good mimic of digestion by an organism, then $44 \%$ of As is removed during digestion in the stomach. The imbibed particles are then excreted and they still contain a significant As concentration, i.e. $\sim 100 \mathrm{mg} \mathrm{kg}^{-1}$. This particle concentration is still well above the PEL and could, if taken up again by an organism, have a secondary effect.

In this study the contaminant metals $\mathrm{Sn}$ and $\mathrm{W}$ had elevated concentrations and EFs. However, currently there are no international standards relating to their bioavailability in soils or sediments. They both warrant further attention because of their potential toxicity. For example, experiments involving Sn species showed they inhibited the growth of planktonic which could evade the sediments and subsequently pass the water-atmosphere interface. The chemical reactivity of $\mathrm{Sn}$ in estuarine sediments may, therefore, contribute to it being lost to the atmosphere (Amouroux et al. 2000). For W, experiments involving low 
589 concentrations of dissolved W resulted in a lower biomass production of the soil micro-

590 organisms Bacilus subtilis and Pseudomonas fluorescence and soils containing low metallic

591 W concentrations impaired the growth of rye grass (Strigul et al. 2005). The physico-

592 chemical form of $\mathrm{W}$ in the impoundment soils is not known, however its low bioavailability of

$5936.5 \%$ (Fig. 6) suggests that the health of the flora growing in the impoundment may be

594 largely unaffected by W.

595

596

597

598

599

600

601

602

603

604

605

606

607

608

609

610 


\section{Conclusions}

612 An impoundment, fitted with regulated tidal exchange, had elevated, and spatially-variable,

613 elemental concentrations in the soils, resulting from the manner in which it was constructed

614 in the mid-19th century. Concentrations of $\mathrm{As}, \mathrm{Pb}$ and $\mathrm{Cu}$ in the impoundment soils were

615 enhanced compared to the national background values in soils and $\mathrm{Sn}$ and $\mathrm{W}$ were

616 elevated. On-going erosion of the ageing protective embankment, enhanced by climatic

617 effects, may result in the tidal incursion of seawater. Along with the parlous state of the

618 embankment, there are fundamental questions concerning the mobilisation of the

619 contaminated soils and their potential impact on estuarine flora and fauna. An effective

620 management strategy is required, including mitigation of the ecotoxicological damage arising

621 from the uncontrolled release of particulate contaminants down-estuary.

622 Set in the international context the Plym impoundment is an example of many ageing

623 impoundments in low-lying coastal zones, some containing contaminated soils, or

624 sediments, that eventually could be vulnerable to re-mobilisation. Given the growing concern

625 about the flood risk to low lying coastal areas, assessing the future management of coastal

626 impoundments is an important issue and the effects of sea level rise and wave action on the

627 stability impoundment barriers need further evaluation. Determining suitable management

628 approaches to protect and preserve these coastal facilities is important, probably on a case

629 by case basis. Consideration should be given to innovative, sustainable management

630 approaches that will adapt to the long-term changes that man-made structures in estuaries

631 are facing worldwide.

632

633

634

635

636 
637 Acknowledgements The authors are grateful to members of staff of Saltram House

638 Plymouth (National Trust), in particular Mr Tony Flux (National Trust Coast \& Marine Adviser

$639(\mathrm{SW}))$. All the chemical and radiological analyses were conducted in the ISO9001:2018

640 accredited Consolidated Radio-isotope Facility at the University of Plymouth. The authors

641 thank Andrew Fisher for his assistance with the ICP-MS analyses and the Cartography Unit

642 at the University of Plymouth. We are grateful to Dr Andrew Turner, University of Plymouth

643 for his critical comments on an early version of this manuscript.

644

645 Funding The research did not receive any specific grant from any funding agency in the 646 public, commercial or not-for-profit sectors.

647

648 Conflict of interest The authors confirm that they have no conflicts of interest.

649

650

651

652

653

654

655

656

657

658

659

660

661

662

663

664 
ABPmer 2017. UK Marine Habitat Creation Schemes: A summary of completed managed realignment and regulated exchange projects (1991-2016). ABPmer White Paper, Report No. R.2781, 20 pp. Electronic database on Habitat Creation Schemes: www.omeg.net

Adam P (2002) Salt marshes in a time of change. Environ Conserv 29: 39-61. https://doi.org/10.1017/S0376892902000048

Amouroux D, Tessier E, Donard OFX (2000) Volatilisation of organotin compounds from estuarine and coastal environments. Environ Sci Technol 3: 988-995. https://doi.org/10.1021/es981025p

Ander EL, Johnson CC, Cave MR, Palumbo-Roe B, Nathanail CP, Lark RM (2013) Methodology for the determination of normal background concentrations of contaminants in English soil. Sci Total Environ 454-455: 604-618. https://doi.org/10.1016/j.scitotenv.2013.03.005

Anisfeld SC, Tobin M, Benoit G (1999) Sedimentation rates in flow-restricted and restored salt marshes in Long Island Sound. Estuar 22: 231-244.

Appleby PG (2001) Chronostratigraphic techniques in recent sediments. In Tracking Environmental Change Using Lake Sediments. Vol. 1: Basin Analysis, Coring and Chronological Techniques (Eds. Last, W.M., Smol, J.P.), Kluwer Academic Publishers, Dordrecht, The Netherlands, pp. 171-203.

Aquatronics (2011) Baseline Surveys of the Hayle Estuary Complex. Consultancy Report. 120 pp. https://www.aquatronics.com

Beauchard O, Jacobs S, Cox TJS, Maris T, Vrebos D, van Braeckel A, Meire P (2011) A new technique for tidal habitat restoration: Evaluation of its hydrological potentials. Ecol Eng 37: 1849-1858. https://doi.org/10.1016/j.ecoleng.2011.06.010

Boyd BM, Sommerfield CK (2016) Marsh accretion and sediment accumulation in a managed tidal wetland complex of Delaware Bay. Ecol Eng 92: 37-46. https://doi.org/10.1016/j.ecoleng.2016.03.045

CCME (1995) Canadian Council of Ministers of the Environment. Canadian Sediment Quality Guidelines for the Protection of Aquatic Life. CCME EPC-98E, Summary Tables. Winnipeg: Environment Canada, 1-5.

Chen S, Taylor J, Baek K, Khan E, Tsang D, Ok Y (2017) Sustainability likelihood of remediation options for metal-contaminated soil/sediment. Chemosphere, 174: 421-427. https://doi.org/j.chemosphere.2017.02.005

DEFRA (2003) Department of the Environment, Food and Rural Affairs. The Use of Action Levels in the Assessment of Dredged Material Placement at Sea and in Estuarine Areas under FEPA (II). CEFAS Report A0258 to DEFRA, 12 pp.

Dixon M, Morris RKA, Scott CR, Birchenough A, Colclough S (2008) Managed realignmentlessons from Wallasea, UK. Proc Inst Civ Eng - Marit Eng 161: 61-71. https://doi.org/maen.2008.161.2.61

Emmerson RHC, Birkett JW, Scrimshaw M, Lester JN (2000) Solid phase partitioning of metals in managed retreat soils: field changes over the first year of a tidal inundation. Sci Total Environ 254: 75-92. https://doi.org/10.1016/S0048-9697(00)00442-3

Emmerson RHC, Scrimshaw M, Birkett JW, Lester JN, (2001) Solid phase partitioning of metals in Managed Realignment soils: laboratory studies in timed soil sea-water batch mixtures. Appl Geochem 16: 1621-1630. https://doi.org/10.1016/S0883-2927(01)00030-0

Esteves LS (2014) Managed Realignment - A Viable Long-Term Coastal Management Strategy? SpringerBriefs in Environmental Science, 158 pp.

Fernández S, Santin C, Marquinez J, Álvarez MA (2010) Saltmarsh soil evolution after land reclamation in Atlantic estuaries (Bay of Biscay, North coast of Spain). Geomorphol 114: 497-507. https://doi.org/j.geomorph.2009.08.014

French PW (2006) Managed realignment-The developing story of a comparatively new approach to soft engineering. Estuar Coast Shelf Sci 67, 409-423. https://doi.org/10.1016/j.ecss.2005.11.035: 
Gedan KB, Silliman BR, Bertness MD (2009) Centuries of human-driven change in salt marsh ecosystems. Annu Rev Mar Sci 1: 117-141.

https://10.1146/annurev.marine.010908.163930

Gu J, Luo M, Zhang X, Christakos G, Agusti S, Duarte CM, Wu J (2018) Losses of salt marsh in China: Trends, threats and management. Estuar Coast Shelf Sci 214: 98-109. https://doi.org/10.1016/j.ecss.2018.09.015

Hanley ME, Bouma TJ, Mossman HL (2020) The gathering storm: optimizing management of coastal ecosystems in the face of a climate driven threat. Ann Bot 125: 197-212. https://doi.org/10.1093/aob/mcz204

Hübner R, Astin KB, Herbert RJH (2010) Dispersal and mobility of metal contamination across a salt marsh from coastal landfill sites using ammonium extractions as an indicator. J Environ Monit 12: 740-747. https://doi.org/10.1039/ba17023e

Jenkin A (2005) Mines of Devon. Ashbourne Landmark Publishing Ltd, pp. 59-76.

Köster HM (1996) Mineralogical and chemical heterogeneity of three standard clay mineral samples. Clay Miner 31: 417-422. https://doi.org/10.1180/claymin.1996.031.3.11

Langston WJ, Chesman BS, Burt GR, Hawkins SJ, Readman J, Worsfold P (2003) Plymouth Sound and Estuaries, sSAC, SPA. Marine Biological Association of the UK, Occasional Publication 09, 202 pp.

Liang Y, Wong MH (2003) Spatial and temporal organic and heavy metal pollution at Mai Po marshes nature reserve, Hong Kong. Chemosphere, 52: 1647-1658. https://doi.org/10.1016/S0045-6535(03)00505-8

Ma C, Zheng R, Zhao J, Han X, Wang L, Gao X, Zhang C (2015) Relationships between heavy metal concentrations in soils and reclamation history in the reclaimed coastal area of Chongming Dongtan of the Yangtze River Estuary, China, J Soils Sediments 15: 139152. https://doi.org/10.1007/s11368-014-0976-3

Macleod CL, Scrimshaw MD, Emmerson RHC, Chang Y-H, Lester JN (1999) Geochemical changes in metal and nutrient loading at Orplands Farm managed retreat site, Essex, UK (April 1995-1997). Mar Pollut Bull 38: 115-1125. https://doi.org/10.1016/S0025326X(99)00141-1

MMO, 2019. Marine Management Organisation. Identifying sites suitable for marine habitat restoration or creation. A report produced for the Marine Management Organisation by ABPmer and AER, MMO Project No. 1135, February 2019, 93 pp.

Masselink G, Hanley ME, Halwyn AC, Blake W, Kingston K, Newton T, Williams M (2017) Evaluation of salt marsh restoration by means of self-regulating tidal gate - Avon Estuary, South Devon, UK. Ecol Eng 106: 174-190. https://doi.org/10.1016/j.ecoleng.2017.05.038

Mazik K, Musk W, Dawes O, Solyanko K, Brown S, Mander L, Elliott M (2010) Managed realignment as compensation for the loss of intertidal mudflat: A short term solution to a long term problem? Estuar Coast Shelf Sci 90: 11-20. https://doi.org/10,1016/j.ecss.2010.07.009

Mossman HL, Davy AJ, Grant A (2012a) Does managed coastal realignment create saltmarshes with 'equivalent biological characteristics' to natural reference sites? J Appl Ecol 49: 1446-1456. https://doi.org/10.1111/j.1365-2664.2012.02198.x

Mossman HL, Brown MH, Davy AJ, Grant A (2012b) Constraints on salt marsh development following managed coastal realignments: Dispersal limitation or environmental tolerance? Restor Ecol 20: 65-75. https://doi.org/10.1111/j.1526-100X.2010.00745.x

Njue CN, Cundy AB, Smith M, Green ID, Tomlinson N (2012) Assessing the impact of historical landfill sites on sensitive ecosystems: A case study from Dorset, Southern England. Estuar Coast Shelf Sci 114: 166-174. https://doi.org/10.1016/j.ecss.2012.08.022

Oosterlee L, Cox TJS, Temmerman S, Meire P (2020) Effects of tidal re-introduction design on sedimentation rates in previously embanked tidal marshes. Estuar Coast Shelf Sci 244: 106428. https://doi.org/10.1016/j.ecss.2019106426

O'Shea F, Cundy A, Spencer K (2018) The contaminant legacy from historic coastal landfills and their potential as sources of diffuse pollution. Mar Pollut Bull 128: 446-455. https://doi.org/10.1016/j.marpolbul.2017.12.047 
Pope ND, O'Hara SCM, Imamura M, Hutchinson TH, Langston WJ (2011) Influence of a collapsed coastal landfill on metal levels in sediments and biota - a portent for the future? J Environ Monit 13: 1961-1874. https://doi.org/10:1039/c0em00741b

Rawlins BG, McGrath SP, Scheib AJ, Breward N, Cave M, Lister TR, Ingram M, Gowing C, Carter S (2012) The Advanced Soil Atlas of England and Wales. British Geological Survey, Keyworth, $227 \mathrm{pp}$.

Riverlevels.uk 2018. River Plym at Carnwood. [online] Available at: https://www.riverlevels.uk/river-plym-bickleigh-carnwood\#.W4RW5fIKiUk [Accessed 27 Aug. 2018].

Robins P, Skov M, Lewis M, Giménez L, Davies A, Malham S, Neill S, McDonald J, Whitton T, Jackson S, Jago C (2016) Impact of climate change on UK estuaries: A review of past trends and potential projections. Estuar Coast Shelf Sci 169: 119-135. https://doi.org/10.1016/j.ecss.2015.12.016

Rollinson GK, Pirrie D, Power MR, Cundy A, Camm GS (2007) Geochemical and mineralogical record of historical mining, Hayle Estuary, Cornwall, UK. Proc Ussher Society, Geosci South-West Engl 11: 326-337.

RSPB (2003) Royal Society for the Protection of Birds. Regulated Tidal Exchange: An InterTidal Habitat Creation Technique. Report, 16 pp. https://www.rspb.org.uk/Images/RTE.tcm9-261368.pdf. [Accessed 13 June 2019].

Rüdel H (2003) Case study: bioavailability of tin and tin compounds. Ecotoxicol Environ Saf 56: 180-189. https://doi.org/10.1016/S01147-6513(03)00061-7

Rushton H, Long S (2015) Blaxden Meadow Management Options. Williams Sale Partnership (WSP), Project no: 70009760. Exeter: WSP, 34 pp.

Spencer KL, Harvey GL (2012) Understanding system disturbance and ecosystem services in restored saltmarshes: Integrating physical and biogeochemical processes. Estuar Coast Shelf Sci 106: 23-32. https://doi.org/10.1016/j.ecss.2012.04.020

Strigul N, Koutsospyros A, Arienti P, Christodoulatos C, Dermatas D, Braida W (2005) Effects of tungsten on environmental systems. Chemosphere, 61: 248-258. https://doi.org/10.1016/j.chemosphere.2005.01.083

Takahashi CK, Turner A, Millward GE, Glegg GA (2012) Persistent and metallic composition of paint particles in sediments from a tidal inlet. Mar Pollut Bull 64: 133-137. https://doi.org/10.1016/j.marpolbul.2011.10.010

Temmerman S, Meire P, Bouma T, Herman PM, Ysebaert T, De Vriend H (2013) Ecosystem-based coastal defence in the face of global change. Nature 504: 79-83. https://doi.org/10.1038/nature12859

Teuchies J, Beauchard O, Jacobs S, Meire P (2012) Evolution of sediment metal concentrations in a tidal marsh restoration project. Sci Total Environ 419: 187-195. https://doi.org/10.1016/j.scitotenv.2012.01.016

Teuchies J, Singh G, Bervoets L, Meire P (2013) Land use changes and metal mobility: Multi-approach study on tidal marsh restoration in a contaminated estuary. Sci Total Environ 449: 174-183. https://doi.org/10.1016/j.scitotenv.2013.01.053

Turner A (2019) Lead pollution of coastal sediments by ceramic waste. Mar Pollut Bull 138: 171-176. https://doi-org/10.1016/j.marpolbul.2018.11.013

VanZomeren CM, Berkowitz JF, Piercy CD, White JR (2018) Restoring a degraded marsh using thin layer sediment placement: Short-term effects on soil physical and biochemical properties. Ecol Eng 120: 61-67. https://doi.org/10.1016/j.ecoleng.2018.05.012

Walling, D., He, Q., 2000. The global distribution of bomb-derived ${ }^{137} \mathrm{Cs}$ reference inventories. IAEA Technical Report 10361/RO-R1, University of Exeter, 17 pp.

Wolters M, Garbutt A, Bakker J.P (2005) Salt-marsh restoration: evaluating the success of de-embankments in north-west Europe. Biol Conserv 123: 249-268. https://10.1016/j.biocon.2004.11.013

Wynants M, Millward G, Patrick A, Taylor A, Munshi L, Mtei K, Brendonck L, Gilvear D, Boeckx P, Ndakidemi P, Blake WH (2020) Determining tributary sources of increased sedimentation in East-African Rift lakes. Sci Total Environ 717: 137266. https://doi.org/10.1016/j.scitotenv.2020.137266 


\section{CAPTIONS TO FIGURES}

Fig. 1 Location of Blaxton Meadow impoundment on the Plym Estuary, Plymouth, UK. The fully analysed cores are numbered 1 to 4 , the Plym core $(P)$ and the partially analysed mini-cores A1-A4 (Supplementary Information S.3). The thick white line defines the embankment undergoing decay and the position of the sluice gate is identified

Fig. 2 Fallout radionuclide activities $\left(\mathrm{Bq} \mathrm{kg}{ }^{-1}\right)$ and the age-depth curve for the impoundment sites 1 to 4 : (1a-4a) ${ }^{137} \mathrm{Cs}$; $(1 \mathrm{~b}-4 \mathrm{~b}){ }^{210} \mathrm{~Pb},{ }^{214} \mathrm{~Pb}$; $(1 \mathrm{c}-4 \mathrm{c})$ age-depth $(\mathrm{O})$ and the dashed line is the sedimentation rate. Fallout radionuclide activities and the age-depth curve for the Plym core: $(\mathrm{Pa}){ }^{137} \mathrm{Cs},(\mathrm{Pb}){ }^{210} \mathrm{~Pb},{ }^{214} \mathrm{~Pb}$ and $(\mathrm{Pc})$ age-depth $(\mathrm{O})$ and the dashed line is the sedimentation rate

Fig. 3 Particulate concentrations of elements in the Plym Estuary Core $(*)$ and the impoundment cores Site $1(\diamond)$; Site $2(\bullet)$; Site $3(x)$; Site $4(x)$ : (a) Fe (\%); (b) Mn $\left(\mathrm{mg} \mathrm{kg}^{-1}\right)$; (c) $\mathrm{Rb}\left(\mathrm{mg} \mathrm{kg}^{-1}\right)$. The vertical dashed lines are the median values for elements in soils from England and Wales (Rawlins et al., 2012)

Fig. 4 Particulate concentrations of elements $\left(\mathrm{mg} \mathrm{kg}^{-1}\right)$ for the Plym Estuary core $(*)$ and the impoundment cores Site $1(\diamond)$; Site $2(\bullet)$; Site $3(x)$; Site $4(x)$ : (a) Cr; (b) Co; (c) Ni; (d) $\mathrm{Cu}$; (e) Zn; (f) As; (g) Sn; (h) W; (i) Pb. The vertical dashed lines are the median values for elements in soils from England and Wales (Rawlins et al., 2012)

Fig. 5 Elemental Enrichment Factors (Mean $\pm 1 \sigma$ ) for sediments from the Plym Estuary core $(\square)$ and soils from the impoundment cores Site $1(\square)$; Site $2(\square)$; Site $3(\square)$; Site $4(\square)$

Fig. 6 Percentage of total elements available to a $1 \mathrm{M} \mathrm{HCl}$ extraction of soil and sediment core sections (a) impoundment soil Core 3, (b) Plym Estuary sediment core. Pb (०); Cu (॰);

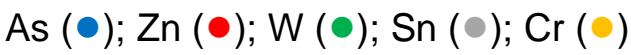



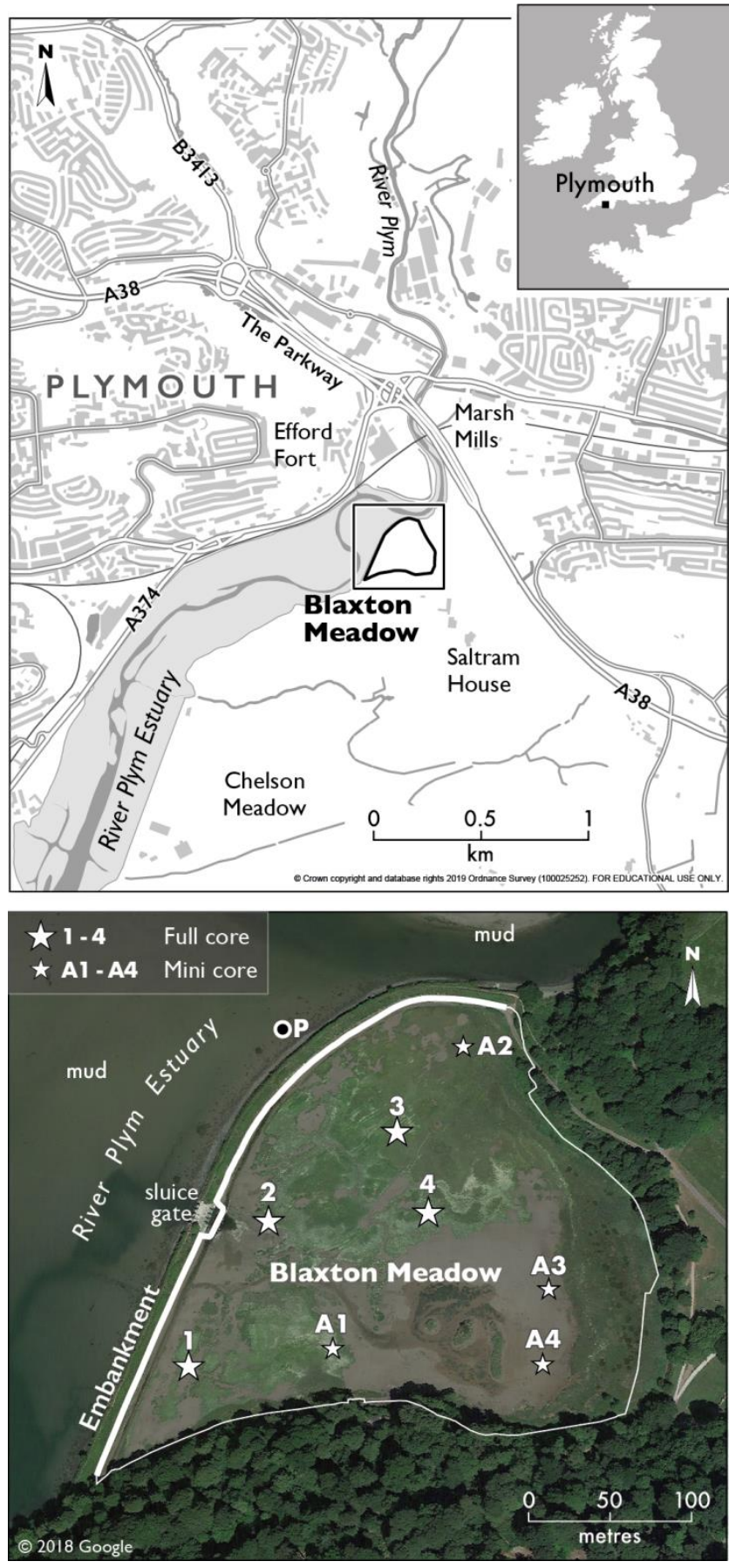

Figure 1 

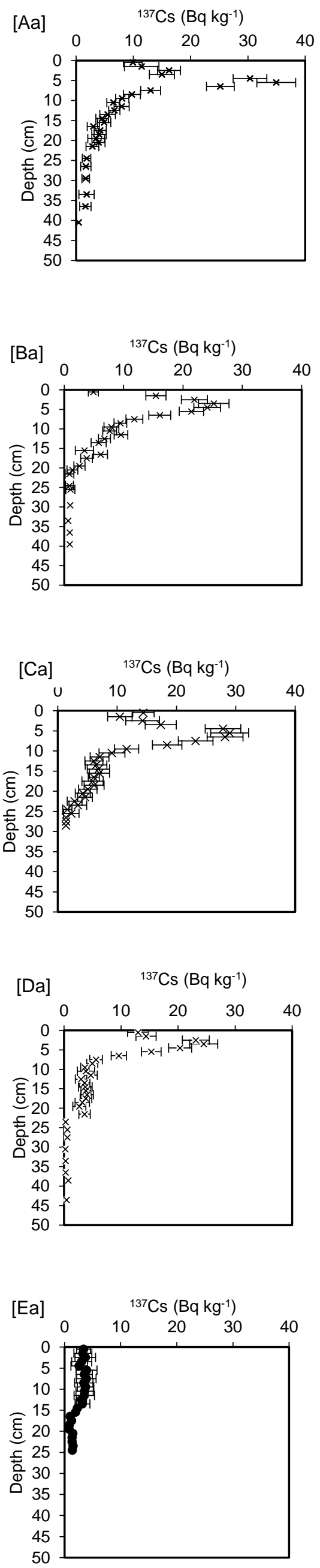
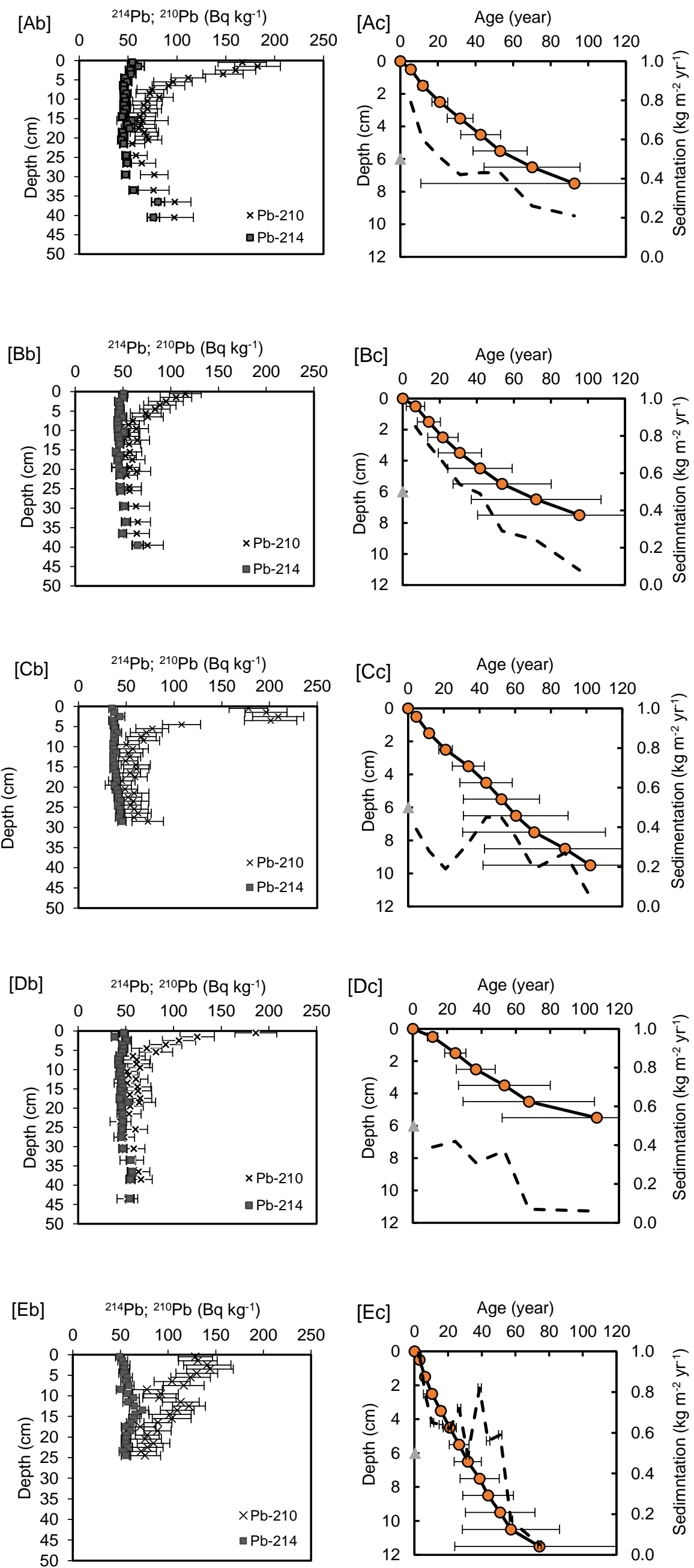

[Ec] Age (year)

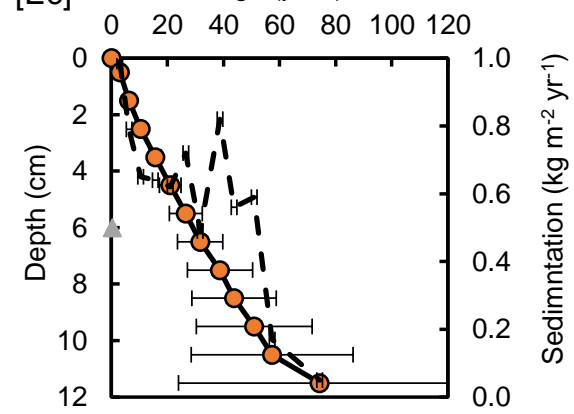


Figure 2
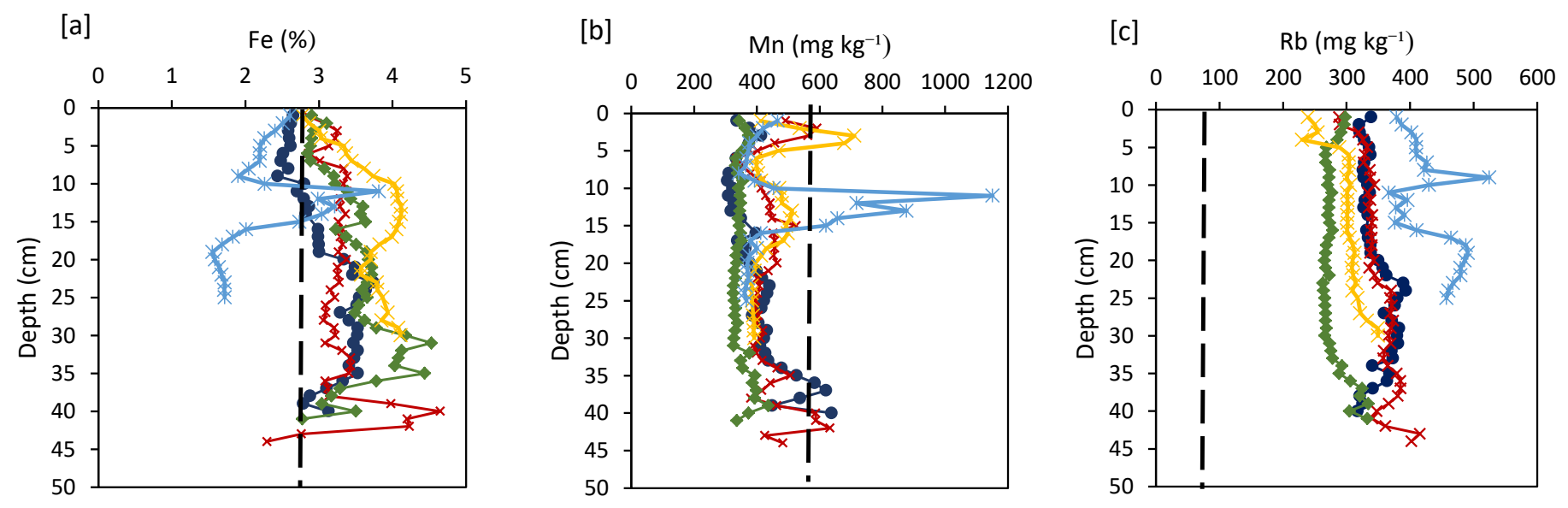

Figure 3 


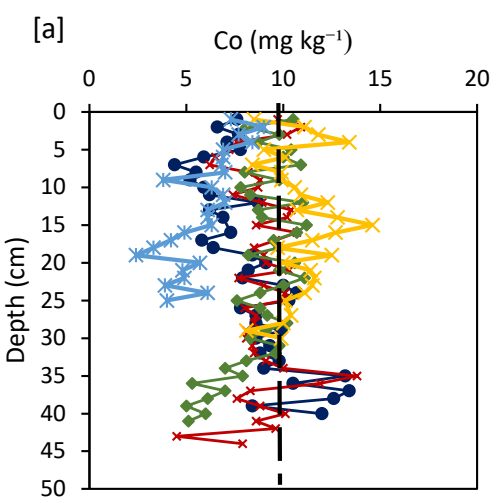

[d]

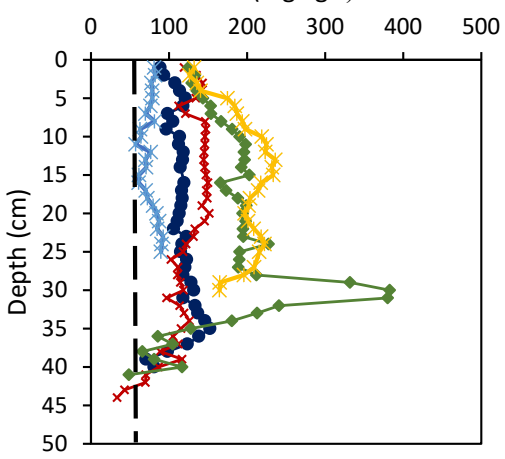

[g]

$\mathrm{Cu}\left(\mathrm{mg} \mathrm{kg}^{-1}\right)$

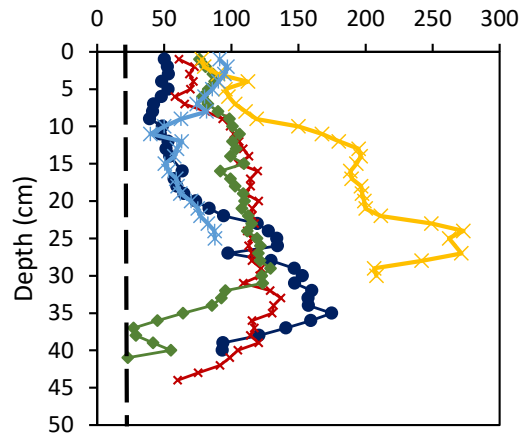

[b]

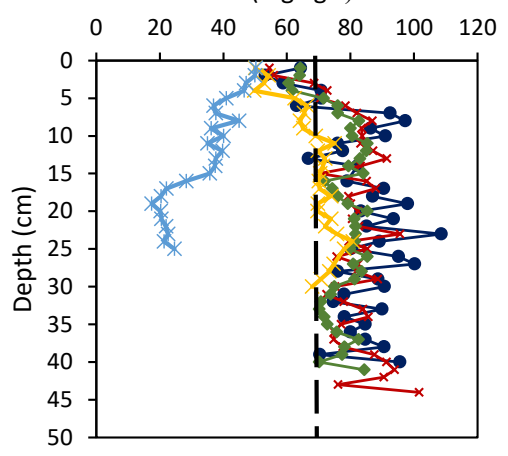

[e]

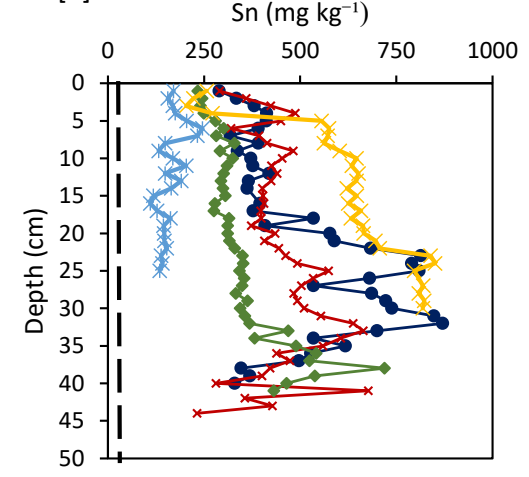

[h]

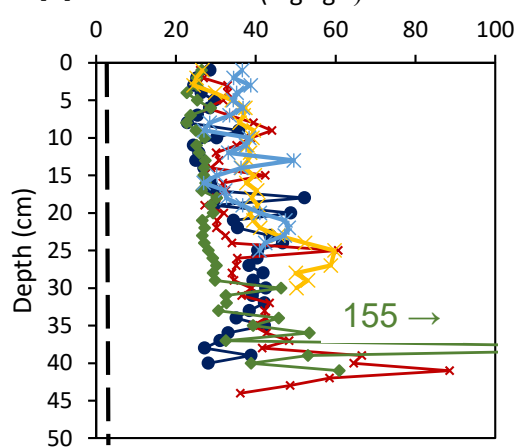

[c] $\mathrm{Ni}\left(\mathrm{mg} \mathrm{kg}^{-1}\right)$

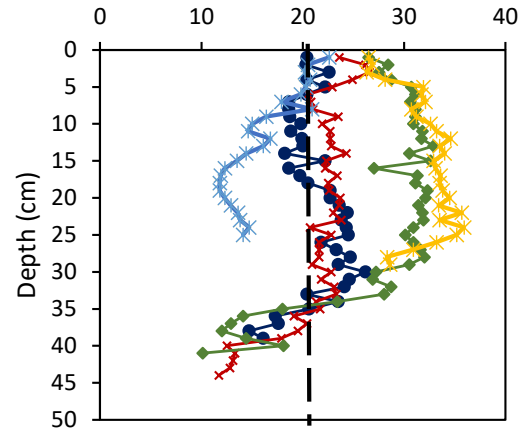

[f] As $\left(\mathrm{mg} \mathrm{kg}^{-1}\right)$
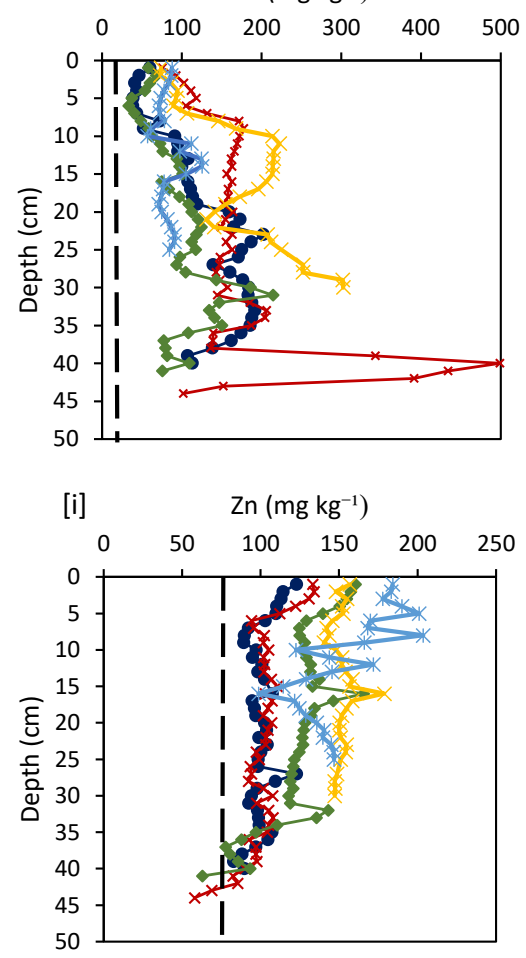

Figure 4 


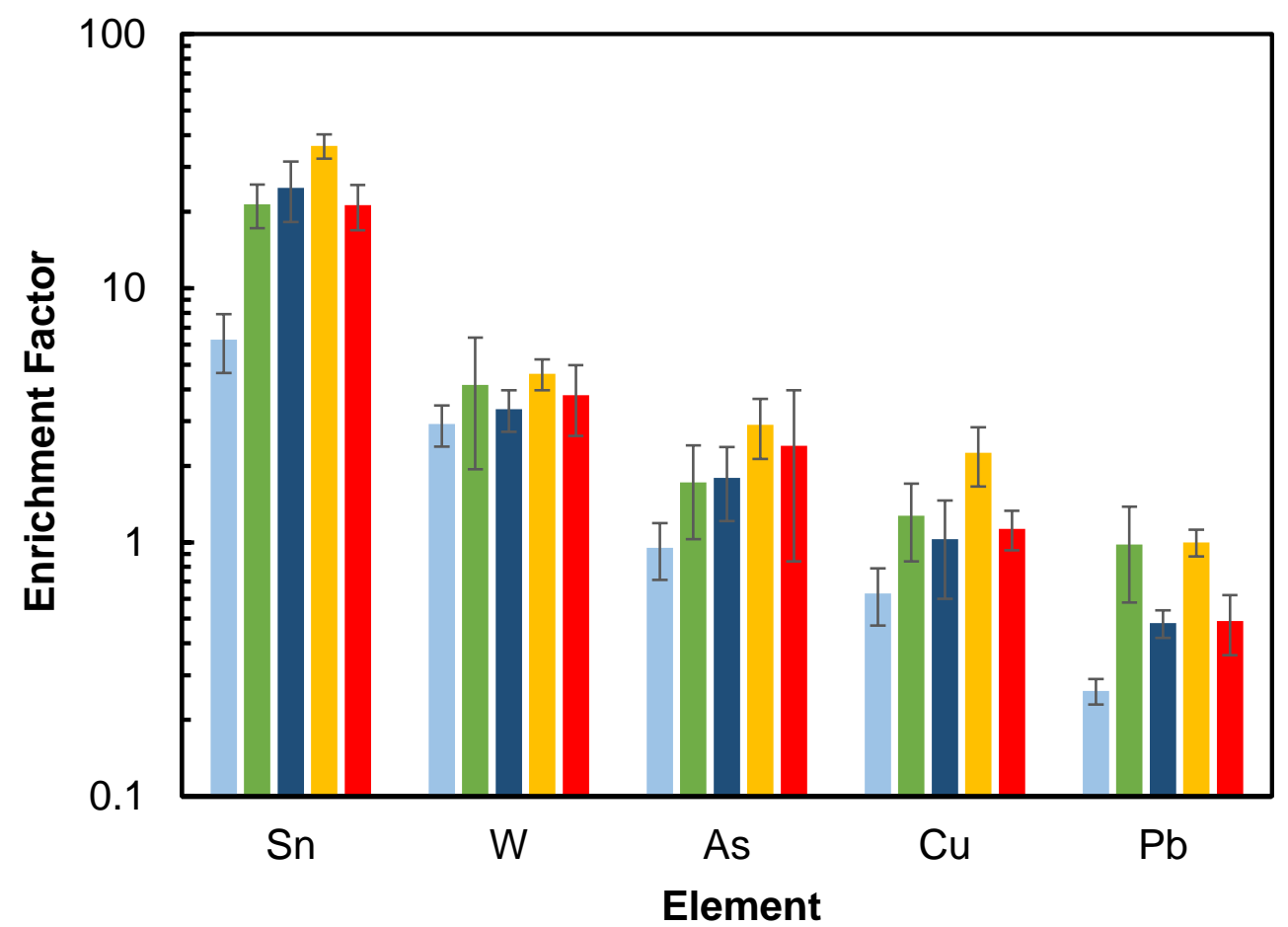

Figure 5 
(a)

Available Metal, \%

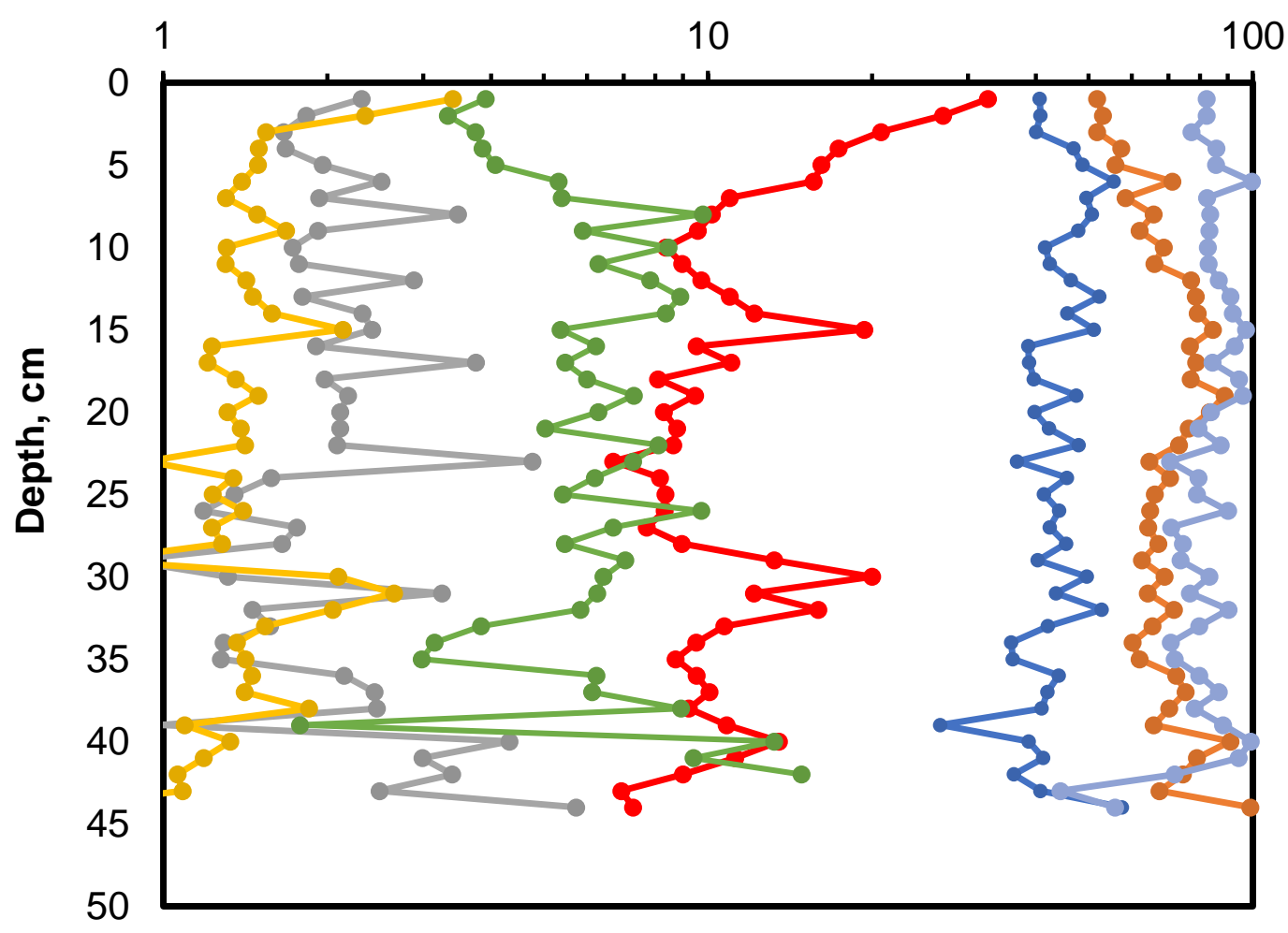

(b)

Available Metal, \%

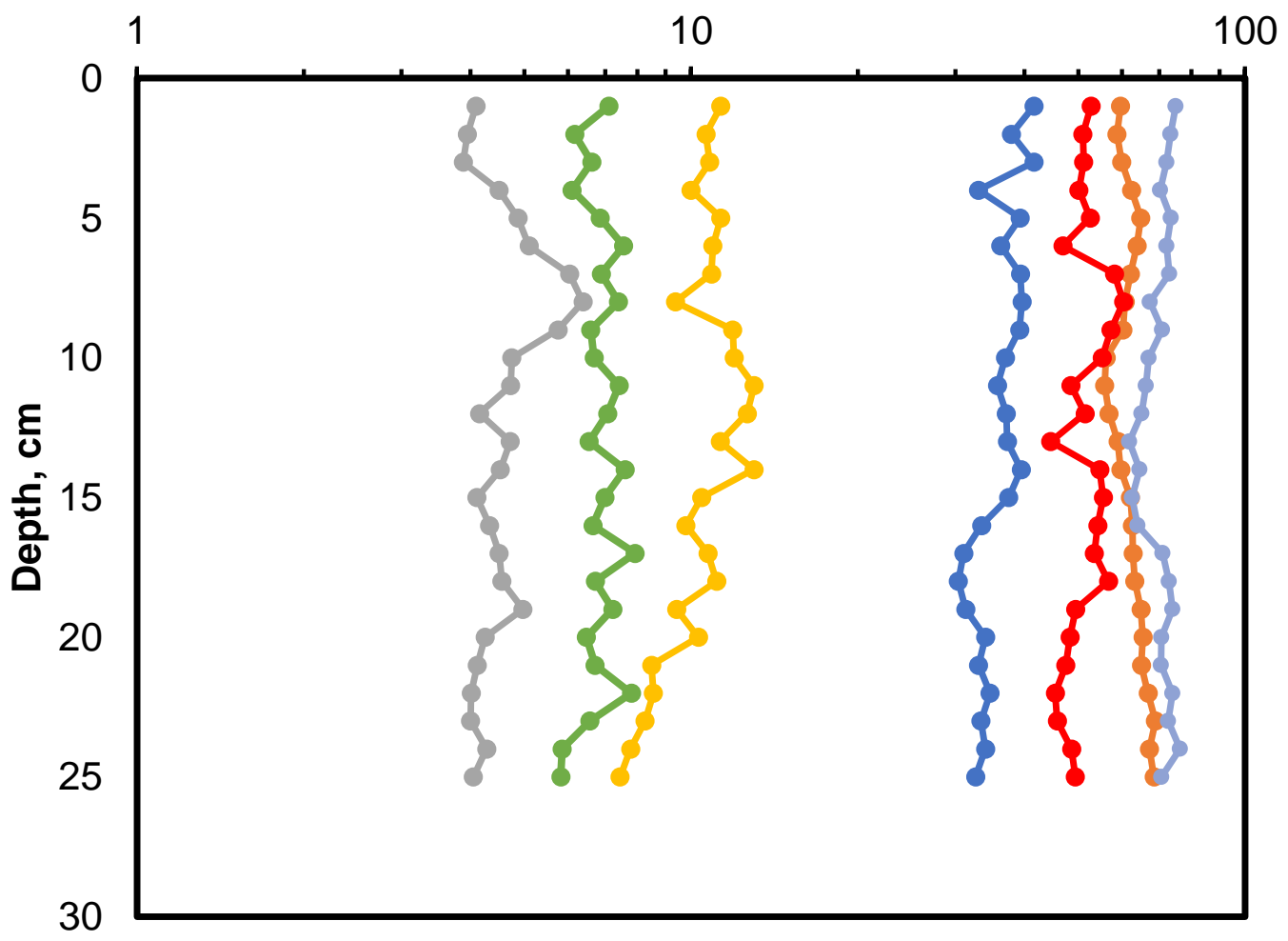

Figure 6 
Table 1 Range of concentrations of total metals in the soils and sediments $\left(\mathrm{mg} \mathrm{kg}^{-1}\right)$ of impoundments, including polders, and examples of intertidal sediments impacted by metal leakage from landfills. The values in brackets are the ranges of percentage metal concentrations available to a $1 \mathrm{M} \mathrm{HCl}$ extraction of solid phases.

\begin{tabular}{|c|c|c|c|c|c|c|c|}
\hline \multirow{2}{*}{$\begin{array}{c}\text { Site } \\
\text { (Area hectares) }\end{array}$} & \multicolumn{6}{|c|}{ Soil or Sediment Concentration, $\mathrm{mg} \mathrm{kg}^{-1}$} & \multirow[b]{2}{*}{ Reference } \\
\hline & As & $\mathrm{Cr}$ & $\mathrm{Cu}$ & $\mathrm{Pb}$ & $\mathrm{Sn}$ & $\mathrm{Zn}$ & \\
\hline $\begin{array}{l}\text { Impoundment Soils and } \\
\text { Blackwater Estuary, UK } \\
\text { Soils (44 ha) }\end{array}$ & its & $38-65$ & $16-28$ & $15-104$ & --- & $59-87$ & Macleod et al 1999 \\
\hline $\begin{array}{l}\text { Mai Po, Hong Kong } \\
\text { Sediments (1500 ha) }\end{array}$ & --- & $11-46$ & $19-87$ & $17-91$ & --- & $56-328$ & Liang \& Wong 2003 \\
\hline $\begin{array}{l}\text { Hayle Estuary, UK } \\
\text { Sediments ( } 6 \text { ha) }\end{array}$ & $211-596$ & $68-167$ & $535-1,510$ & $83-214$ & $70-166$ & $386-911$ & Aquatronics 2011 \\
\hline $\begin{array}{l}\text { Scheldt Estuary, Belgium } \\
\text { Polder Soils ( } 8 \text { ha) }\end{array}$ & $10.7-57.1$ & $48.2-710$ & $29.8-173$ & $64.2-323$ & --- & $308-1,640$ & Teuchies et al 2013 \\
\hline $\begin{array}{l}\text { Yangtze Estuary, China } \\
\text { Soils (1858 ha) }\end{array}$ & --- & $55-77$ & $26-48$ & $23-37$ & --- & $90-125$ & Ma et al 2015 \\
\hline $\begin{array}{l}\text { Plym Estuary, UK } \\
\text { Soils ( } 5.5 \text { ha) }\end{array}$ & $\begin{array}{c}33-505 \\
(36-58 \%)\end{array}$ & $\begin{array}{c}50-109 \\
(0.6-2.7 \%)\end{array}$ & $\begin{array}{c}7-175 \\
(52-99 \%)\end{array}$ & $\begin{array}{c}34-380 \\
(44-97 \%)\end{array}$ & $\begin{array}{l}231-871 \\
(0.9-5 \%)\end{array}$ & $\begin{array}{l}58-166 \\
(7-33 \%)\end{array}$ & This Work \\
\hline \multicolumn{8}{|c|}{ Intertidal Sediments impacted by decaying landfills } \\
\hline Christchurch Harbour, UK & $0.34-13$ & 3.3-54 & $4.4-34$ & $4.7-61$ & $0.1-2.3$ & $10-170$ & Hübner et al 2010 \\
\hline Lyme Bay, UK & $\begin{array}{c}3.6-10 \\
(3.3-42 \%)\end{array}$ & $\begin{array}{c}10-22 \\
(0.1-5.0 \%)\end{array}$ & $\begin{array}{c}11-64 \\
(13-32 \%)\end{array}$ & $\begin{array}{c}14-153 \\
(25-63 \%)\end{array}$ & --- & $\begin{array}{c}41-278 \\
(10-38 \%)\end{array}$ & Pope et al 2011 \\
\hline Thames Estuary, UK & --- & $7-91$ & 4-74 & $8-205$ & --- & $22-262$ & O'Shea et al 2018 \\
\hline
\end{tabular}


Table 2 Mean $( \pm 1 S D)$ metal concentrations in the Plym Estuary core sediments and the impoundment soil cores from sites 1-4. The sequence of the elements is organised to cohere with the sequence in Fig. 4.

\begin{tabular}{|c|c|c|c|c|c|c|c|c|c|}
\hline \multirow{2}{*}{ Location } & \multicolumn{9}{|c|}{ Sedimentary Metal Concentrations, $\mathrm{mg} \mathrm{kg}^{-1}$} \\
\hline & Co & $\mathrm{Cr}$ & $\mathbf{N i}$ & $\mathbf{P b}$ & Sn & As & $\mathrm{Cu}$ & $\mathbf{W}$ & $\mathbf{Z n}$ \\
\hline Plym Estuary & $5.9 \pm 1.6$ & $33.4 \pm 10.3$ & $16.0 \pm 3.4$ & $76.1 \pm 9.8$ & $161 \pm 33$ & $84.9 \pm 17.1$ & $71.6 \pm 15.9$ & $37.0 \pm 6.4$ & $152 \pm 28$ \\
\hline \multicolumn{10}{|l|}{ Impoundment } \\
\hline Site 1 & $8.8 \pm 1.7$ & $79.0 \pm 4.8$ & $27.4 \pm 6.5$ & $180 \pm 69$ & $354 \pm 98$ & $97 \pm 39$ & $92 \pm 38$ & $35.2 \pm 22.2$ & $124 \pm 23$ \\
\hline Site 2 & $8.5 \pm 2.3$ & $84.6 \pm 10.0$ & $21.1 \pm 2.7$ & $115 \pm 16$ & $517 \pm 175$ & $126 \pm 54$ & $93 \pm 45$ & $34.9 \pm 7.6$ & $101 \pm 8.8$ \\
\hline Site 3 & $10.8 \pm 1.5$ & $68.2 \pm 7.9$ & $32.0 \pm 2.7$ & $196 \pm 31$ & $623 \pm 180$ & $177 \pm 65$ & $175 \pm 59$ & $40.2 \pm 8.8$ & $152 \pm 7.0$ \\
\hline Site 4 & $8.8 \pm 1.6$ & $83.0 \pm 6.8$ & $21.3 \pm 3.5$ & $121 \pm 28$ & $450 \pm 94$ & $174 \pm 85$ & $103 \pm 22$ & $70.0 \pm 12.5$ & $101 \pm 14$ \\
\hline
\end{tabular}


Table 3 Inventories, $\mathrm{g} \mathrm{m}^{-2}$, of elements for each core. Total inventories estimated assuming the mean inventory is representative over the area of the impoundment, 5.5 ha.

\begin{tabular}{cccccccc}
\hline \multirow{2}{*}{ Site } & \multicolumn{7}{c}{ Elemental Inventories, $\mathrm{g} \mathrm{m}^{-2}$} \\
\cline { 2 - 8 } & $\mathrm{As}$ & $\mathrm{Cu}$ & $\mathrm{Pb}$ & $\mathrm{Sn}$ & $\mathrm{Cr}$ & $\mathrm{W}$ & $\mathrm{Zn}$ \\
\hline $\begin{array}{c}\text { Plym Estuary Core } \\
\text { Impoundment Cores }\end{array}$ & 27 & 22 & 24 & 52 & 11 & 11 & 47 \\
1 & 21 & 26 & 46 & 77 & 20 & 6.8 & 34 \\
2 & 42 & 27 & 43 & 185 & 32 & 13 & 40 \\
3 & 52 & 55 & 63 & 195 & 21 & 12 & 46 \\
4 & 53 & 36 & 48 & 127 & 29 & 12 & 37 \\
Inventory Mean & 42 & 36 & 50 & 146 & 26 & 11 & 39 \\
Total, t & 2.3 & 2.0 & 2.8 & 8.0 & 1.4 & 0.6 & 2.2 \\
\hline
\end{tabular}


Table 4 DEFRA (2003) action level guidelines (A1=disposal at sea and A2=no disposal at sea) for disposal of dredged material at sea, and concentration ranges of impoundment sediment cores. CSQG criteria (CCME, 1995), where less than the TEL=the minimal concentration below which adverse effects rarely occur; between the TEL and PEL=the concentration range within which adverse effects occasionally occur; above the PEL=concentration above which adverse effects frequently occur. All concentrations are in $\mathrm{mg} \mathrm{kg}^{-1}$ (dry weights).

\begin{tabular}{|c|c|c|c|c|c|c|c|c|}
\hline \multirow{3}{*}{ Metal } & \multicolumn{4}{|c|}{ Contaminant Criteria, mg kg-1 } & \multirow{2}{*}{\multicolumn{4}{|c|}{ Mean Metal Concentrations $( \pm 1 \sigma), \mathrm{mg} \mathrm{kg}^{-1}$}} \\
\hline & \multicolumn{2}{|c|}{ DEFRA } & \multicolumn{2}{|c|}{ CSQG } & & & & \\
\hline & A1 & A2 & TEL & PEL & Site 1 & Site 2 & Site 3 & Site 4 \\
\hline As & 20 & 100 & 7.24 & 41.6 & $97 \pm 39$ & $126 \pm 54$ & $177 \pm 65$ & $174 \pm 85$ \\
\hline $\mathrm{Cr}$ & 40 & 400 & 52.3 & 160 & $79 \pm 4.8$ & $85 \pm 10$ & $68 \pm 7.9$ & $83 \pm 6.8$ \\
\hline $\mathrm{Cu}$ & 40 & 400 & 18.7 & 108 & $92 \pm 28$ & $93 \pm 45$ & $175 \pm 59$ & $103 \pm 22$ \\
\hline $\mathrm{Pb}$ & 50 & 500 & 30.2 & 112 & $180 \pm 69$ & $115 \pm 16$ & $196 \pm 31$ & $121 \pm 28$ \\
\hline Zn & 130 & 800 & 124 & 271 & $124 \pm 23$ & $101 \pm 8.8$ & $152 \pm 7.0$ & $101 \pm 14$ \\
\hline
\end{tabular}

